(10) norden

\title{
7 veje mod fremtidens nordiske velfærd
}

Globaliseringsinitiativet for sundhed og velfærd

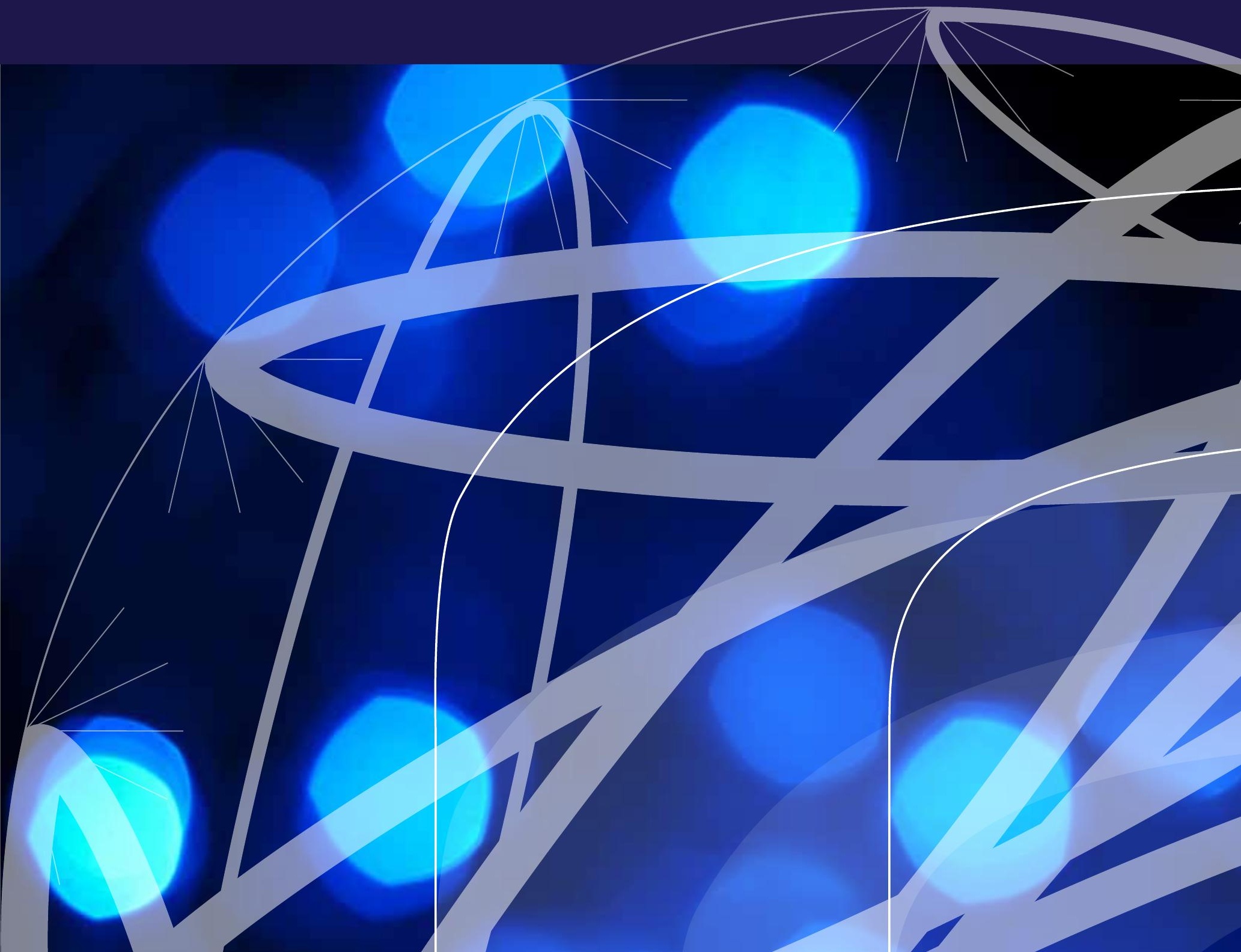




\section{7 veje mod fremtidens nordiske velfærd}

Globaliseringsinitiativet for sundhed og velfærd

Mandag Morgen

\section{ISBN 978-92-893-2572-1}

http://dx.doi.org/10.6027/ANP2013-746

ANP 2013:746

(C) Nordisk Ministerråd 2013

Layout: Erling Lynder/Jette Koefoed

Korrektur: Mie Bardrum

Omslagsfoto: imageSelect

Foto: ImageSelect

www.norden.org/da/publikationer

Nordiska Ministerråd

\section{Ved Stranden 18}

DK-1061 København K

Telefon (+45) 33960200

www.norden.org

\section{Det nordiske samarbejde}

Det nordiske samarbejde er en af verdens mest omfattende regionale samarbejdsformer. Samarbejdet omfatter Danmark, Finland, Island, Norge og Sverige samt Færøerne, Grønland og Åland.

Det nordiske samarbejde er både politisk, økonomisk og kulturelt forankret, og er en vigtig medspiller i det europæiske og internationale samarbejde. Det nordiske fællesskab arbejder for et stærkt Norden i et stærkt Europa.

Det nordiske samarbejde ønsker at styrke nordiske og regionale interesser og værdier i en global omverden. Fælles værdier landene imellem er med til at styrke Nordens position som en af verdens mest innovative og konkurrencedygtige regioner. 


\title{
7 veje mod fremtidens nordiske velfærd
}

\section{Globaliseringsinitiativet for sundhed og velfærd}

\author{
5 Forord \\ 7 Det nordiske samarbejde vender store velfærdsudfordringer \\ til fælles styrkepositioner \\ 15 Projekt 1: \\ Nordisk indsats kan inkludere flere unge, funktionshindrede \\ og ældre på arbejdsmarkedet \\ 21 Projekt 2: \\ Arbejdsindvandring afslører den nordiske models blinde pletter \\ 27 Projekt 3: \\ Nordiske vækstvirksomheder efterlyser konkurrencedygtig \\ arbejdskraft \\ 31 \\ Projekt 4: \\ Forældre får hjælp til at fremme børnenes sundhed \\ 35 Projekt 5: \\ Fællesnordiske målinger bidrager til bedre kost- og \\ motionsvaner \\ 39 Projekt 6: \\ Bedre skolemadsordninger kan forbedre børns sundhed og læring \\ 43 \\ Projekt 7: \\ Nordiske regioner samarbejder om mere innovation i \\ sundhedssektoren \\ 49 Nye perspektiver: \\ Det nordiske samarbejde sætter fokus på holdbar nordisk velfærd
}




\section{Om Globaliseringsinitiativet for sundhed og velfærd}

De nordiske samarbejdsministre (MR-SAM) besluttede den 15. oktober 2009 at indlede en række globaliseringsinitiativer i år 2010, blandt andet globaliseringsinitiativet inden for sundhed og velfærd.

Globaliseringsinitiativet for sundhed og velfærd er et sammenhængende treårigt program, som består af syv selvstændige delprojekter. Initiativet har til formål at bidrage til den nordiske velfærdsmodels holdbarhed og konkurrencekraft med fokus på centrale nordiske velfærdsudfordringer. Via et tværsektorielt nordisk samarbejde er der udviklet løsninger inden for udvalgte områder på sundheds- og velfærdsområdet for at skabe synergi og nordisk merværdi.
Programmet tager afsæt i to hovedtemaer, som gensidigt skal styrke hinanden: (1) Velfærd - generel udvikling og kompetenceudvikling i arbejdsstyrken samt inkludering og (2) Sundhed - fremme en sund og arbejdsdygtig befolkning samt livskvalitet. Programmets syv selvstændige delprojekter er placeret under de to hovedtemaer.

Seks ministerråd - Nordisk Ministerråd for Arbejdsliv (MR-A), Nordisk Ministerråd for Erhvervs-, Energi- og Regionalpolitik (MR-NER), Nordisk Ministerråd for Fiskeri, Havbrug, Jordbrug, Levnedsmidler og Skovbrug (MR-FJLS), Nordisk Ministerråd for Ligestilling (MR-JÄM), Nordisk Ministerråd for Social- og Helsepolitik (MR-S), Nordisk Ministerråd for Uddannelse og Forskning (MR-U) er involveret i programmet.

\section{Periode}

Programmet er implementeret i perioden 2010-2012.

\section{Budgetinformation}

Indikativ planlægningsramme:

37,5 mio. DKK.

\section{Kontaktpersoner}

Maria-Pia de Palo, seniorrådgiver, mpp@norden.org Izabela Butenko-Olesen, projektmedarbejder, izbu@norden.org 


\section{Forord}

Den globale konkurrenceøkonomi betyder hårdere international konkurrence og gør stadige produktivitetsog kvalitetsforbedringer nødvendige.

Med store ligheder mellem de nordiske lande er det oplagt at lære af hinandens erfaringer med at indrette os i en verden i forandring. Vores stærke historiske og kulturelle fællesskab og den ensartede institutionelle opbygning giver os store muligheder for at lære af hinandens erfaringer og udvikle nye løsninger sammen. Gennem et tæt og fokuseret samarbejde mellem landene kan vi vende presserende velfærdsudfordringer til nordiske styrkepositioner.

Det er ud af dette fokus, at Globaliseringsinitiativet for sundhed og velfærd blev igangsat. Initiativet skal levere viden, løsninger og inspiration til, hvordan de nordiske lande sammen møder de udfordringer, som globaliseringen stiller landene over for. Det handler om, hvordan vi sammen kan sætte fokus på at øge den nordiske velfærdsmodels holdbarhed og konkurrencekraft.
Vi har allerede mange gode erfaringer med det nordiske samarbejde, men potentialet er endnu større. Derfor har jeg som nyudnævnt generalsekretær et særligt fokus på, hvordan vi kan forbedre det nordiske samarbejde og skabe nye løsninger i fællesskab.

Det styrkede samarbejde skal tage udgangspunkt i de udfordringer og muligheder, som globaliseringen giver vores region. Globaliseringens konsekvenser fylder meget i den offentlige debat $i$ alle de nordiske lande, og det er derfor oplagt at tænke løsninger på tværs af landegrænserne. Sammen kan vi sætte gang i mere. Sammen kan vi forbedre mulighederne for at holde fast i de fælles kerneværdier om et stærkt socialt sikkerhedsnet, et højt uddannelsesniveau, høj beskæftigelse samt udnyttelse af nye tanker og teknologier i såvel den offentlige som den private sektor.

Den røde tråd, der binder de syv delprojekter i globaliseringsinitiativet sammen, er da også netop dette.
Hvordan kan fælles nordiske løsninger bidrage til at videreudvikle den nordiske model, således at den også fremover er økonomisk bæredygtig?

Resultatet er blevet en masse ny viden, en række konkrete løsninger og gode eksempler til inspiration og efterfølgelse, der kan danne grundlag for de kommende års samarbejde. Det er disse resultater, som denne publikation præsenterer i lettilgængelig form. Publikationen består af en samlende artikel, syv projektportrætter og en perspektivartikel. Den er udarbejdet af tænketanken Mandag Morgen.

Globaliseringsinitiativet for sundhed og velfærd bidrager med både retning og viden til en udvikling af det nordiske samarbejde. Jeg ser frem til at det gode arbejde med at videreudvikle den nordiske velfærdsmodel i Nordisk Ministerråd fortsætter i det nye program Holdbar Nordisk Velfærd.

Dagfinn Høybråten

Generalsekretær, Nordisk Ministerråd 
„Hverken de enkelte regeringer eller virksomheder kan håndtere globaliseringens udfordringer på egen hånd“". Halldor Ásgrímsson 


\section{Det nordiske samarbejde vender store velfærdsudfordringer til fælles styrkepositioner}

\section{Hovedpointer}

- De nordiske lande er gået sammen om at løse nogle af de mest presserende udfordringer, som regionen står over for. Det er sket i erkendelsen af, at landene ikke kan klare udfordringerne alene.

- Samtidig rummer globaliseringen også betydelige muligheder for vækst og udvikling, hvor Norden kan udvikle sine styrkepositioner til at gentænke den nordiske model samt skabe nye erhvervseventyr.

- Nordisk Ministerråd har derfor søsat Globaliseringsinitiativet for sundhed og velfærd, der gennem syv delprojekter har givet bud på, hvordan dele af velfærds- og sundhedssektoren i de nordiske lande kan videreudvikles.
Verden er i opbrud. En række afgørende tendenser præger udviklingen og kan ændre spillets gang og føre til store forskydninger i de kommende år. Som grundlæggeren af World Economic Forum, Klaus Schwab, formulerer det: „Lederskabet udfordres af jordskælv, der finder sted på mange forskellige områder: i økonomien, geopolitikken, samfundet, miljøet, teknologien og så videre. Ingen kan benægte, at verden er i en flydende tilstand, og de afledte radikale forandringer er særligt krævende for beslutningstagerne“.

Tænketanken Mandag Morgen har identificeret syv forbundne kriser, der påvirker udviklingen i det internationale samfund. Se figur 1 . De griber ind i hinanden i et komplekst dynamisk samspil, hvor udviklingen på ét område lynhurtigt kan forandre vilkårene fundamentalt på et andet. Det stiller helt nye krav til beslutningstagerne om at udvikle sammenhængende svar og grænseoverskridende løsninger.
Mange har endnu ikke erkendt rækkevidden af disse fundamentale forandringer og drømmer måske stadig om at vende tilbage til den gamle normalitet med forudsigelige vækstrater og støt stigende velstand og velfærd. Men det scenarie virker mere og mere som en umulighed.

De nordiske lande er gået sammen om at løse nogle af de mest presserende udfordringer, som globaliseringen stiller regionen over for. Det er netop sket $i$ erkendelsen af, at ,hverken de enkelte regeringer eller virksomheder kan håndtere globaliseringens udfordringer på egen hånd“, som tidligere generalsekretær i Nordisk Ministerråd, Halldor Ásgrímsson, udtalte i forbindelse med de nordiske statsministres skelsættende møde i 2007 i den finske by Punkaharju. Her blev statsministrene enige om at fokusere det nordiske samarbejde på, hvordan den nordiske model kunne videreudvikles til at håndtere globaliseringens udfordringer.

Den fælles front er siden da kun blevet vigtigere, i takt med at den globale

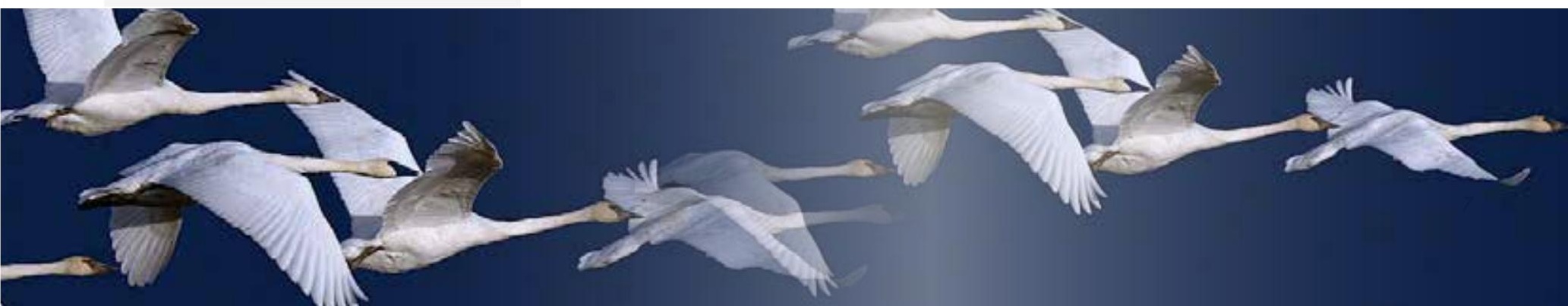




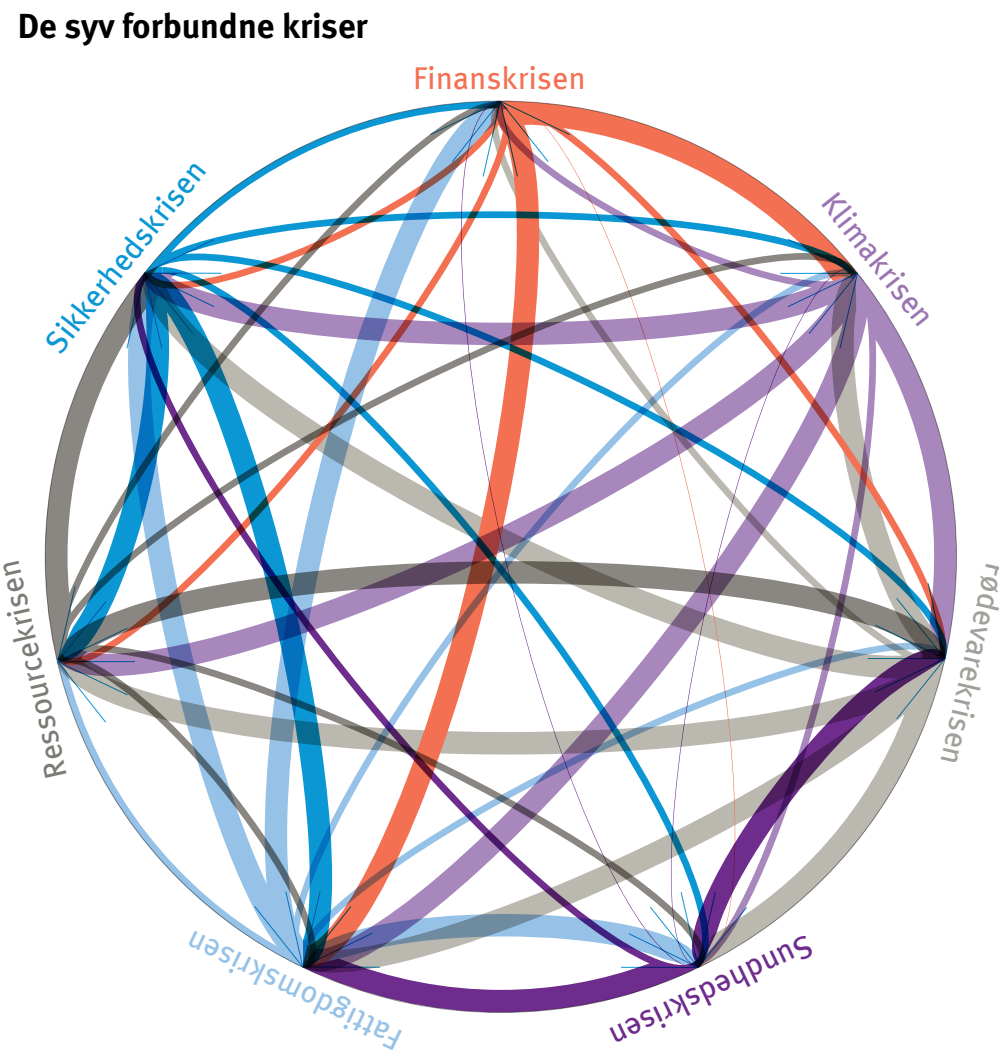

Figur 1: Der er et komplekst samspil mellem de syv forbundne internationale kriser, der påvirker hinanden gensidigt. Stregernes tykkelse angiver, hvor stærk den indbyrdes påvirkning er: En fed streg = stærk påvirkning; halvfed streg = middel påvirkning; tynd streg = lille påvirkning. udvikling har taget uforudsete drejninger. Finanskrise, økonomikrise og eurokrise har vendt op og ned på den globale arbejdsdeling. Samtidig giver udviklingen unikke muligheder for de nordiske lande og virksomheder. Det amerikanske analysehus McKinsey vurderer eksempelvis i en ny rapport, at en eksplosivt voksende middelklasse i lande som Kina, Indien og Brasilien vil øge udviklingsøkonomiernes samlede forbrug med 18.000 milliarder dollar over de næste 15 år. Det er ikke mindst efterspørgsel på sundheds- og velfærdsløsninger, der vil drive forbruget i udviklingsøkonomierne.

\section{Den nordiske model er en juvel}

For de nordiske lande hænger en udnyttelse af mulighederne og en forbedring af konkurrenceevnen tæt sammen med en videreudvikling af det, vi er fælles om: den nordiske model. I alle landene er universelle velfærdsydelser og en sammentænkning af velfærds- og arbejdsmar- 
kedspolitikker helt grundlæggende i den institutionelle opbygning.

Derfor er det afgørende spørgsmål, hvordan modellen kan udvikles, så vi i Norden bliver i stand til at håndtere de skiftende globale vilkår og gribe de nye muligheder, der opstår. Det var da også drivkraften bag de nordiske statsministres valg om at fokusere det nordiske samarbejde. Se boks.

Det nye fokus i det nordiske arbejde har været en succes, og interessen for den nordiske model er enorm. For nylig dedikerede det velansete tidsskrift The Economist et helt temanummer til det, de kaldte „The Next Supermodel“.

The Economist opfordrer andre lande til at tage ved lære af den nordiske pragmatisme og viljestyrke til at finde, og om nødvendigt genopfinde, løsninger, der virker. De underbygger deres pointe med et tankeeksperiment: „Hvis du, som en person

\section{De nordiske lande er konkurrencedygtige}

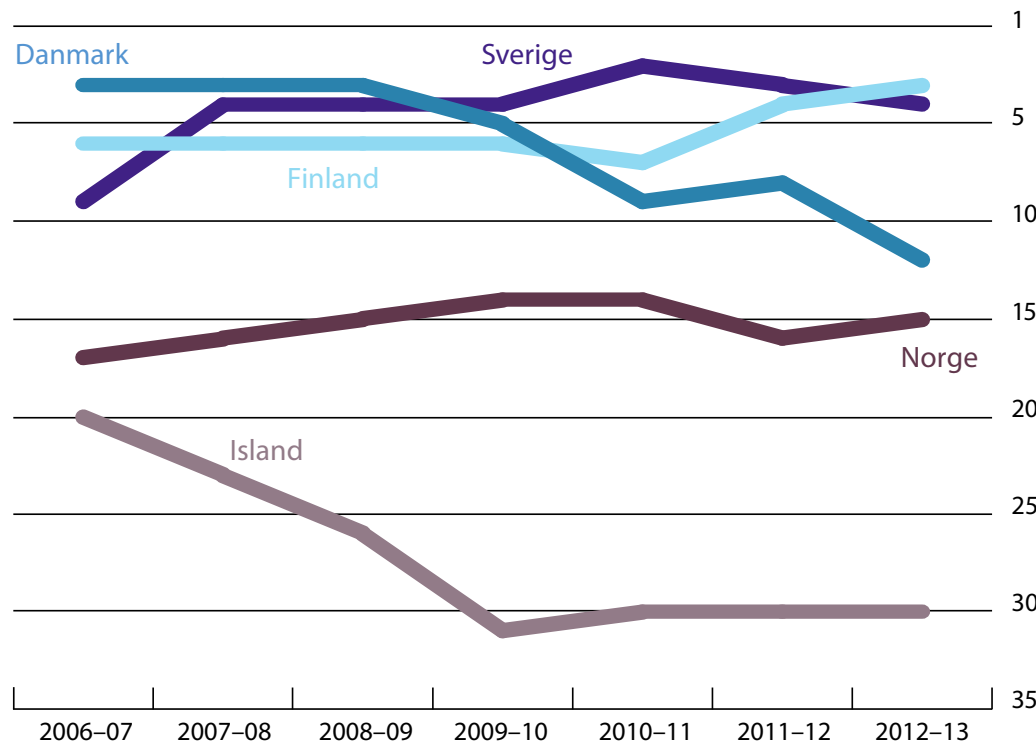

Figur 2: Særligt Finland, Sverige og Danmark har de seneste ti år ligget i front $\mathrm{i}$ internationale sammenligninger. Det viser en gennemgang af de nordiske landes placering på World Economic Forums årlige Global Competitiveness Index.

Kilde: World Economic Forum

med gennemsnitlige talenter og en gennemsnitlig indkomst kunne blive genfødt et valgfrit sted $i$ verden ville du ønske at blive viking“.
Der er ifølge The Economist to gode grunde til at se nærmere på de nordiske lande. For det første har flere af de nordiske lande længe ligget i 


\section{Den nordiske model er billig}

Sociale nettoudgifter

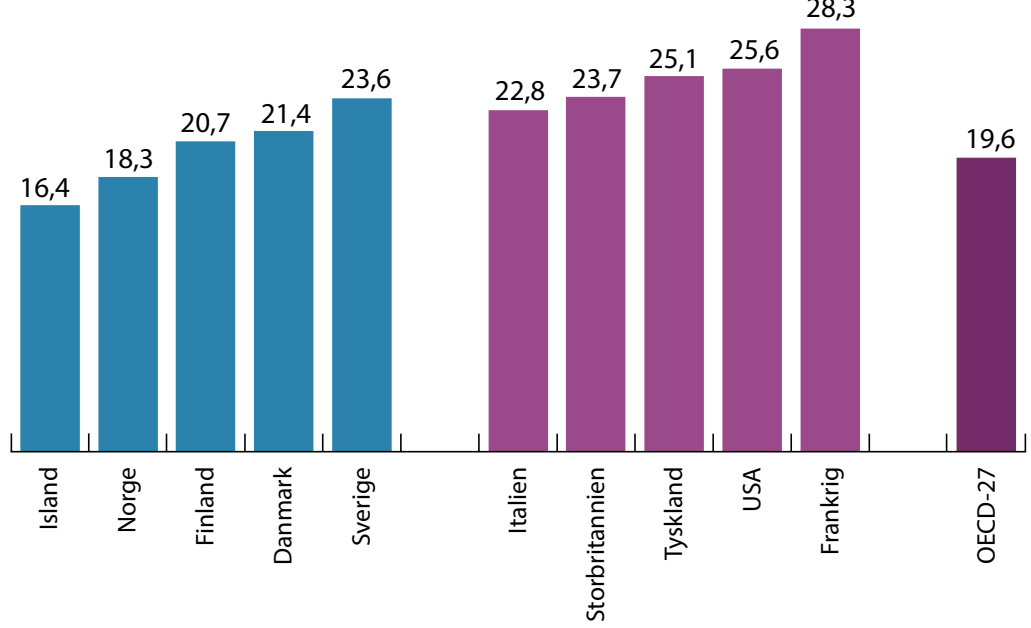

Figur 3: De nordiske landes velfærdssystemer er ikke dyre i international sammenligning. De samlede nettoomkostninger angiver den andel af BNP, der anvendes på velfærdsydelser (sundhedssystemet, sociale ydelser, pensioner og arbejdsløshedsunderstøttelse) fra både offentlige og private kasser. Tallene er fra 2007.

Kilde: OECD (2011): „Is the European welfare state really more expensive?“

spidsen af de internationale opgørelser over produktivitet og konkurrenceevne og samtidig undgået „Sydeuropas økonomiske sklerose og USA's ekstreme ulighed“. Se figur 2.
For det andet har „de nordiske lande nået fremtiden først“. The Economist nævner som eksempel, at andre lande er tvunget til at opfinde nye tilbud om børnepasning, i takt med at

\section{Globaliseringsinitiativet for sundhed og velfærd}

Globaliseringsinitiativet for sundhed og velfærd er et sammenhængende program, der gennem en treårig periode fra 2010 til 2012 har været en vigtig driver i det nordiske samarbejde. Programmet fokuserer på den nordiske velfærdsmodels bæredygtighed og konkurrencekraft med udgangspunkt i centrale velfærdsudfordringer.

Konkret består globaliseringsinitiativet af syv selvstændige projekter kategoriseret under de to hovedtemaer, sundhed og velfærd. Projekterne har udviklet ny viden, konkrete anbefalinger og nye løsninger. Sådan bidrager de til at skabe gode rammevilkår for et konkurrencedygtigt erhvervsliv, en effektiv arbejdsmarkedsregulering og bedre inklusion af stadig flere grupper på arbejdsmarkedet.

Initiativet er Nordisk Ministerråds flagskibsprojekt inden for sundhed og velfærd, og det samlede initiativ er finansieret inden for budgetrammen på 37,5 millioner danske kroner. 
veluddannede kvinder træder ind på arbejdsmarkedet. Det samme gælder en række andre velfærds- og sundhedsløsninger, som vi enten allerede har $\mathrm{i}$ Norden eller er i gang med at udvikle. Og faktisk viser OECD's internationale sammenligninger, at de sociale systemer $\mathrm{i}$ Norden samtidig er billigere end $\mathrm{i}$ lande som Frankrig og USA. Se figur 3.

„Den nordiske model er en juvel, som vi skal passe godt på. Vi omtales med beundring uden for Norden, senest $i$ en forsidehistorie $i$ The Economist $i$ februar. I en kriseramt verden under økonomisk pres vender mange blikket mod de nordiske erfaringer. Jeg vil gerne være en katalysator med henblik på fortsat at fremme vores fællesskab“, siger den nyudpegede generalsekretær for Nordisk Ministerråd, norske Dagfinn Høybråten.

\section{Det tværsektorielle samarbejde styrkes}

Globaliseringsinitiativet for sundhed og velfærd skal ses i lyset af det om fattende udviklings- og innovations-

\section{Globaliseringsinitiativet for sundhed og velfærd}

\section{Projekterne}

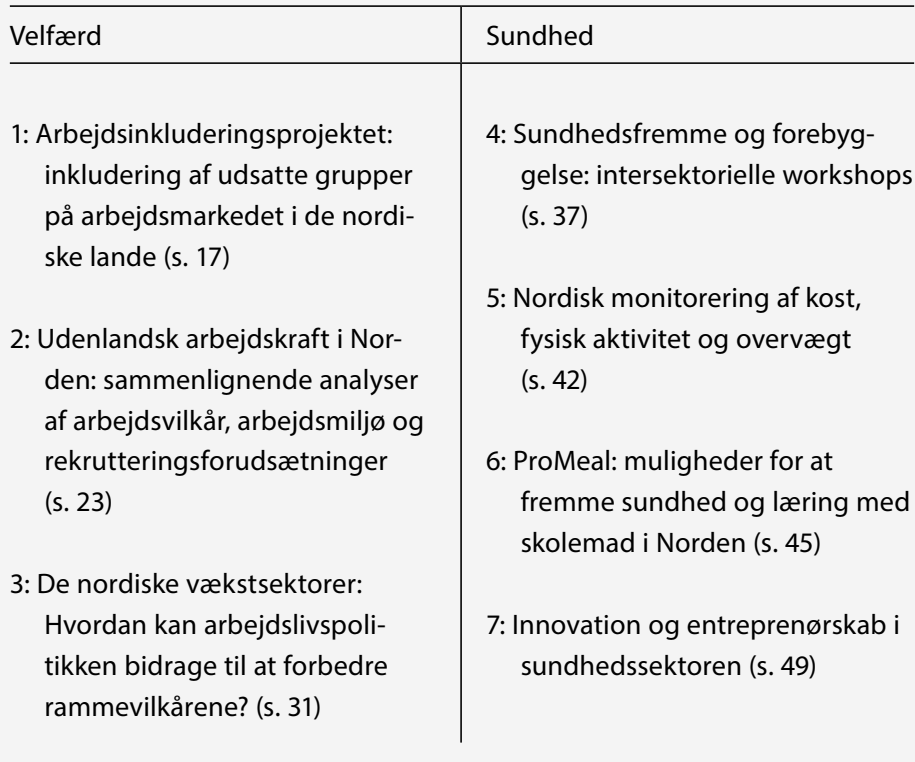

arbejde, der er i gang på sundhedsog velfærdsområdet i Norden. Seniorrådgiver Maria-Pia de Palo, der har stået for den overordnede udvikling og koordinering af initiativet, siger:
„Ministerrådets globaliseringsinitiativ har først og fremmest bidraget til at skabe en fælles nordisk vidensplatform på dette felt. Vi er lykkedes med at bringe nordiske eksperter

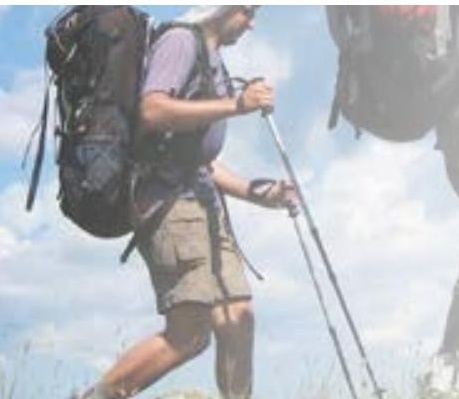




\title{
„I en kriseramt verden under økonomisk pres ven- der mange blikket mod de nordiske erfaringer".
}

\author{
Dagfinn Høybråten
}

\begin{abstract}
sammen og få dem til at arbejde sammen om at håndtere et kompliceret sæt af velfærdsudfordringer - der i praksis får betydning for de fleste menneskers hverdag. Resultatet her, tre år efter vi gik i gang, er syv bud på konkrete velfærdsløsninger“.

Se boks.
\end{abstract}

De syv projekter i globaliseringsinitiativet er gennemført i et bredt tværsektorielt samarbejde. „Projektets ambition om at samarbejde på tværs af seks ministerråd har været en krævende opgave. Som projektleder har jeg skullet håndtere et kompliceret sæt af udfordringer, hvor vante måder at arbejde på ikke slår til“, siger Maria-Pia de Palo og fortsætter: „Vi har arbejdet aktivt med at opbygge nye og dynamiske samarbejdsrelationer på tværs af organisationen. Det er lykkedes et godt stykke hen ad vejen, takket være et stort engagement fra projektdeltagere og kolleger. Jeg ser derfor globaliseringsinitiativet som en vigtig byggeklods, som fremtidige projekter kan bygge videre på - især når det gælder tværsektorielt samarbejde i de nordiske lande“.

\section{Fremtidssikret velfærd}

Konkrete udfordringer med at skabe gode rammevilkår for et konkurrencedygtigt erhvervsliv, en effektiv arbejdsmarkedsregulering og inklusion af stadig flere grupper på arbejdsmarkedet er temaer for globaliseringsinitiativets tre første delprojekter under overskriften „Velfærd“.

Studerer man de enkelte projekter $\mathrm{i}$ Nordisk Ministerråds globaliseringsinitiativ, står det klart, at svarene på de centrale udfordringer for velfærdsog arbejdsmarkedspolitikken kan bygge videre på grundstenene i den nordiske model. Selvom udfordringerne er alvorlige, er der behov for reformer mere end revolution. Projekterne arbejder derfor med at gentænke nogle af de elementer og tilgange, der tidligere har givet de nordiske lande succes.
De nordiske lande har eksempelvis en lang historie med at føre en erhvervspolitik, der skaber gode rammevilkår for private virksomheder. Det skyldes ikke bare, at eksporten har afgørende betydning for de fem små åbne økonomier. Det skyldes også en bred politisk konsensus om, at de private virksomheder i sidste ende udgør det skattegrundlag, der skal finansiere den offentlige sektor. Det gælder både globale nordiske virksomheder - som Statoil, Volvo, Nokia og Lego - og de små og mellemstore virksomheder, der udgør en mere anonym, men mindst lige så vigtig del af job- og vækstskabelsen i Norden.

En aktuel udfordring for nordiske politikere er, hvordan man understøtter de virksomheder, som skaber jobs, der er konkurrencedygtige på et globalt marked. „De nordiske lande har jo ikke specielt meget ud af, hvis der bliver skabt jobs i virksomheder, som ikke er i stand til at konkurrere“,

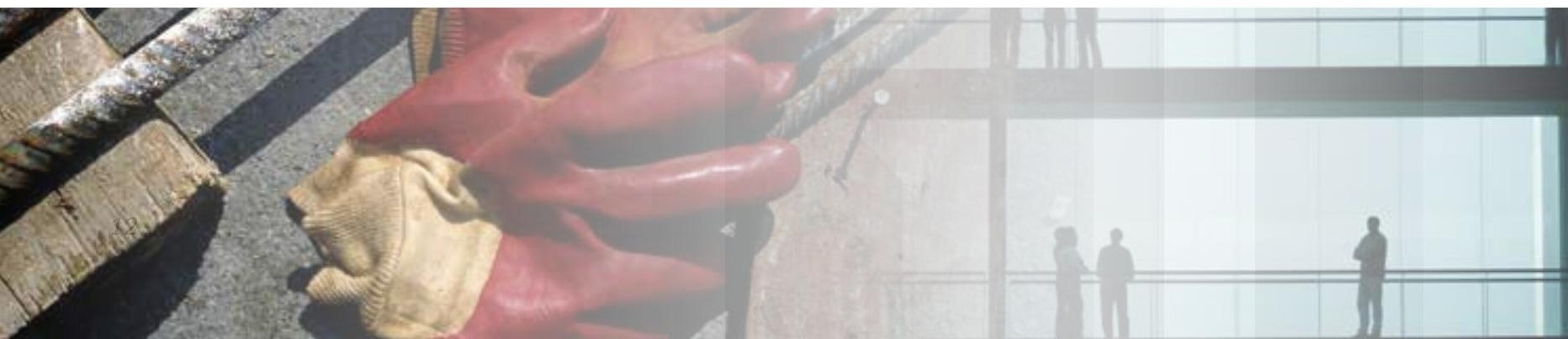




\section{„Jeg ser derfor globaliseringsinitiativet som en vigtig byggeklods, som fremtidige projekter kan bygge videre på - især når det gælder tværsektorielt samarbejde i de nordiske lande“. Maria-Pia de Palo}

siger Lars Foldspang fra konsulentvirksomheden Damvad. „Vi leder efter de virksomheder, der kan tilbyde fremtidens jobs“, siger han om den unders $\varnothing$ gelse, virksomheden har udarbejdet som en del af globaliseringsinitiativet. Se projekt 3.

Et andet kendetegn ved den nordiske model er den ikke-statslige regulering af arbejdsmarkedet, hvor arbejdsmarkedets parter selv forhandler om lønog arbejdsvilkår. Det har hidtil været en effektiv reguleringsmetode, men den er nu under pres, fordi „den nuværende arbejdsindvandring er langt større end det, vi har oplevet tidligere“, siger Søren Kaj Andersen, lektor på Københavns Universitet. For ham og hans kolleger er det afgørende at undersøge, hvordan de nordiske lande undgår, at arbejdsmigrationen skaber et parallelt arbejdsmarked med risiko for social dumping. Problematikken er højaktuel i hele Norden. I Danmark har Københavns Kommune, efter flere afsløringer af social dumping, set sig nødsaget til at indføre en skærpet kontrol med de entreprenører, der arbejder for kommunen.

Se projekt 2.

Et tredje aspekt er den velkendte sammenligning af den nordiske model med en humlebi, der ifølge fysikkens love ikke burde kunne flyve. Således har økonomividenskabens modeller svært ved at forklare, hvordan lande med en stor offentlig sektor og højt skattetryk kan være konkurrencedygtige og økonomisk bæredygtige. Et afgørende element i succesen er den høje erhvervsfrekvens. Særligt på grund af kvindernes deltagelse på arbejdsmarkedet er den betydeligt højere end i de lande, vi normalt sammenligner os med. The Economist roser da også de nordiske lande for „en stærk track record med at trække på hele befolkningens talenter" og peger på, at inklusionen af alle grupper på arbejdsmarkedet fortsat bør være et fokusområde for landene. Se projekt 1.

\section{En endnu bedre offentlig sektor er nødvendig}

Den anden side af den nordiske model er en omfattende offentlig sektor, som varetager en lang række opgaver for borgeren. Her er sikringen af adgangen til af høj kvalitet behandling ved sygdom et kerneelement, og et område, som lægger beslag på en meget stor del af de offentlige udgifter.

Udgiftspresset vil i de kommende år vokse yderligere. Det skyldes ikke mindst en stigning $i$ antallet af borgere med alvorlige livsstilssygdomme. Ikke kun fordi vi lever længere, men også fordi børn og unge i dag rammes tidligere af overvægt, sukkersyge og lignende sygdomme. Derfor er det af afgørende betydning at bevidstgøre forældre og de andre aktører omkring barnet om risikofaktorer og, især, hvad der fremmer børnenes sundhed. Det siger Karin Ringsberg, professor på Nordiska högskolan för folkhälsovetenskap i Göteborg. Derfor har

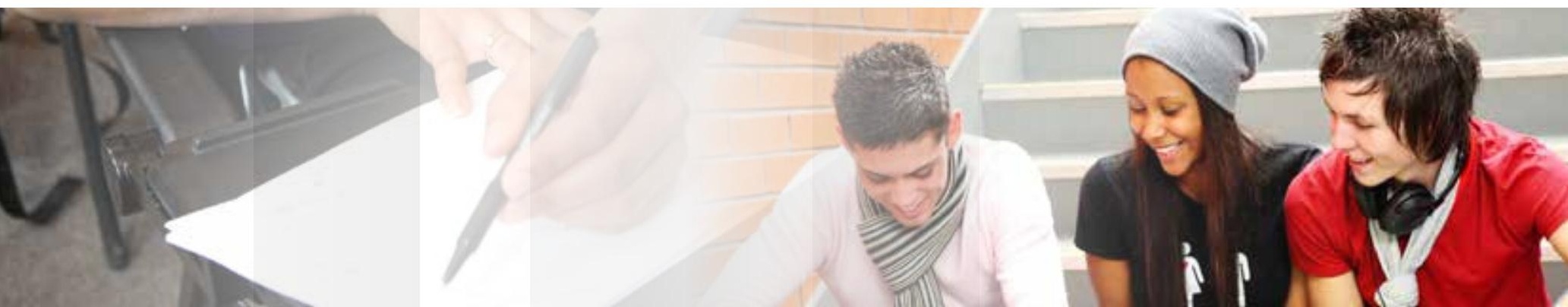


hun, som en del af globaliseringsinitiativet, udviklet en unik model for, hvordan familier kan hjælpes til en sundere livsstil. Disse workshops kan nu benyttes frit fra www.nordiskalivsstilsverkstan.com. Se projekt 4.

Samtidig er befolkningen i de nordiske lande vant til behandlingstilbud af høj kvalitet og stiller generelt store krav til sundhedsvæsenet. Derfor er det helt afgørende, at vi formår at udnytte den teknologiske udvikling, hvis vi vil sikre behandlinger af en høj kvalitet og samtidig skabe et innovativt og effektivt sundhedsvæsen, der er økonomisk bæredygtigt. Det kræver nye samarbejder mellem det offentlige og de private virksomheder: „Den teknologiske udvikling i sundhedssektoren går så hurtigt, at det er nødvendigt at have en mere åben dialog med leverandørindustrien“, siger Bjørn Grønli, der er head of innovation for Helse Sør-Øst, en af Norges fire sundhedsregioner. Han har for Nordisk Ministerråd undersøgt mulighederne for et bedre offentlig-privat-innovationssamarbejde i de nordiske sundhedssektorer og har inden for rammerne af projektet skabt en platform for et formaliseret samarbejde mellem en række nordiske helseregioner.

\section{Forebyggelse præger fremtidens sundhedssektor}

Det samlede fokus for de øvrige fire delprojekter i globaliseringsinitiativet er da også på, hvordan sundhedssektoren i Norden kan blive mere forebyggende, effektiv og innovativ. I disse fire projekter eksemplificeres nogle af de værdier, som også tidligere har kendetegnet udviklingen af den nordiske model, og der fokuseres ikke mindst på, hvordan de nordiske lande vil have gavn af et $\emptyset$ get samarbejde. Se projekt 5 .

The Economist lægger stor vægt på, at man ikke bør forstå den omfattende stat som et udtryk for mangel på individualisme. Faktisk tværtimod, skriver tidsskriftet med henvisning til, at de nordiske befolkninger, ifølge World Values Survey, er de mest individualistiske i verden. I stedet bruger The Economist begrebet „stats-individualisme“, hvor grundtanken er, at den offentlige sektor skal sikre muligheder og social mobilitet for den enkelte borger.

Derfor er den optimale hjælp fokuseret på at være myndiggørende - det er hjælp til, at borgeren kan hjælpe sig selv. I arbejdet med at forebygge livsstilssygdomme bliver spørgsmålet, hvordan offentlige ressourcepersoner kan øge borgernes kompetencer til selv at kunne vælge det sunde. En anden grundværdi er, at de nordiske landes offentlige sektorer fors $\varnothing$ ger at sætte tidligere og bredere ind og forebygge frem for at behandle. Det handler om at skabe sunde rammer frem for at hjælpe de enkelte, der er kommet i problemer. Hvis man vil håndtere livsstilssygdomme, handler det derfor om at sikre, at børn og

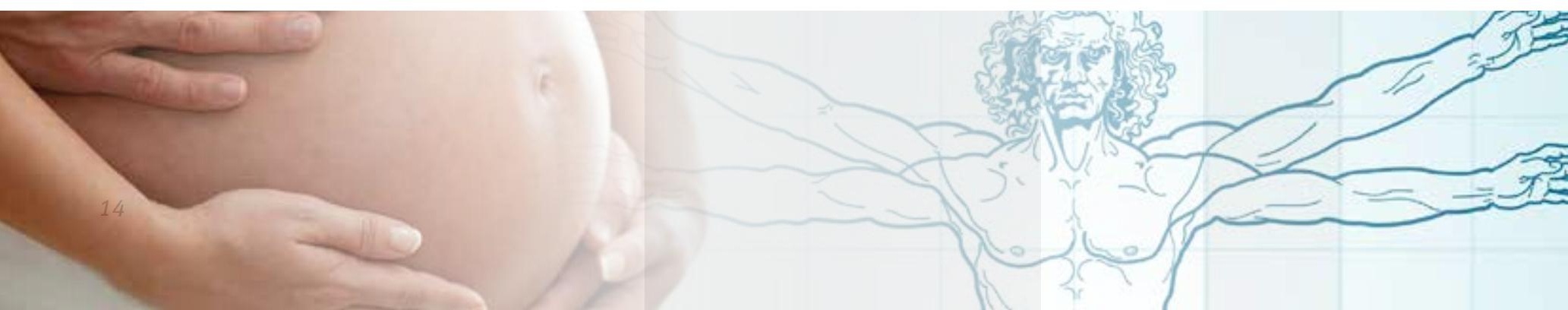


unge både får de bedste forudsætninger og tidligt bliver præsenteret for de sunde valg som den oplagte løsning. Se projekt 6.

Sidst, men ikke mindst, giver den teknologiske udvikling store muligheder for at tilbyde bedre behandlinger til syge borgere. At udnytte teknologien er dog i sig selv en udfordring, for den er ikke nødvendigvis uproblematisk at implementere i en kompleks behandlingssituation. Lykkes det, er der omvendt et enormt potentiale for at sprede løsningerne internationalt.

\section{Nye samarbejder kan blive nor- disk eksporteventyr}

Der er mulighed for at genopfinde nordiske landes gode erfaringer med et konstruktivt samarbejde mellem offentlige og private aktører, sådan at private virksomheder kan udfordre og servicere den offentlige sektor med nytænkende løsninger. Et sådant samarbejde kan ikke bare sikre en mere effektiv sundhedssektor, men rummer også muligheder for et nyt nordisk eksporteventyr.

„Vi har i Norge gennem tæt samarbejde mellem køber og leverandør opbygget en førende leverandørindustri til olieindustrien, og Norden har potentiale for at gøre det samme for velfærds- og sundhedsleverandører. Der er et meget stort marked“, siger Morten Andreasen, der er direktør i den norske virksomhed Imatis, der leverer elektroniske whiteboards til sygehuse i blandt andet Danmark. Se projekt 7.

The Economist bemærker den nordiske evne til at skabe pragmatiske løsninger, hvor forskellige aktører samarbejder om at finde fælles svar på de udfordringer og risici, de deler. Det er netop med ambitionen om at fortsætte denne tradition, at de syv delprojekter i globaliseringsinitiativet er designet. Projekterne integrerer forskellige aktører fra de nordiske lande i et forsøg på at nytænke nogle af de mest presserende udfordringer, og samtidig inviterer de til at tænke på tværs og lære af hinandens løsningsforslag.

På denne måde bidrager projekterne med ny inspiration til, hvordan de nordiske lande kan bygge videre på tidligere succeser. Konklusionen er, at denne tilgang både kan håndtere globaliseringens udfordringer og gøre de nordiske lande endnu bedre til at gribe de nye muligheder.

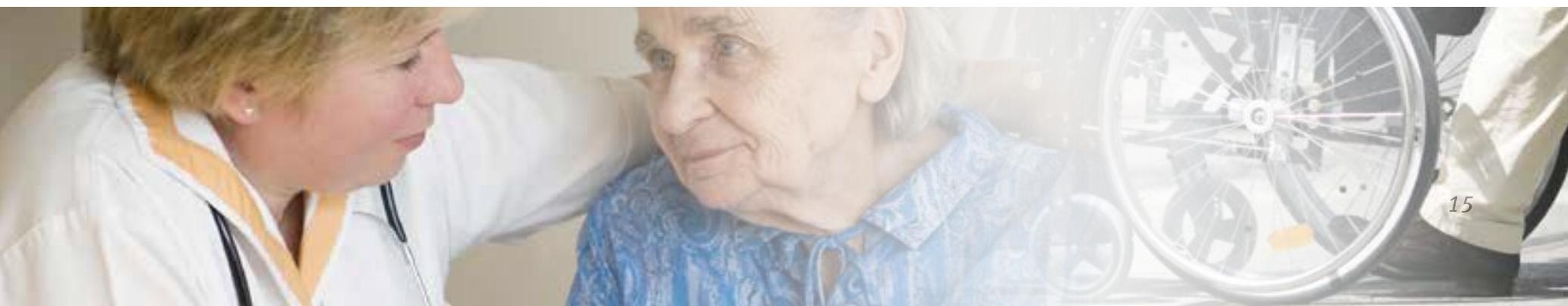


„Vi har undersøgt, hvad landene faktisk gør for at inkludere tre af de udsatte grupper

- de unge, funktionshindrede og seniorer - for at finde gode eksempler på, hvad der ser ud til at give resultater".

Bjørn Halvorsen 


\section{Nordisk indsats kan inkludere flere unge, funktionshindrede og ældre på arbejdsmarkedet}

\section{Hovedpointer}

- 5 til 10 pct. af alle unge i Norden er i risiko for permanent at ende uden for arbejdsmarkedet. Det svarer til 300.000 unge. Det viser en ny undersøgelse af unge, funktionshindrede og seniorers arbejdssituation, som Nordens Velfærdscenter har udarbejdet.

- Den omfattende unders $\varnothing$ gelse viser samtidig, at mellem 3 og 5 pct. af alle unge i Norden allerede er permanent ekskluderet fra arbejdsmarkedet. Det svarer til mellem 70.000 og 150.000 unge.

- Den gode nyhed er, at der er gode muligheder for, at de nordiske lande kan bruge hinandens erfaringer til at løse inklusionsproblemer for forskellige udsatte grupper.
300.000 unge i Norden risikerer at ende med aldrig at opnå en varig tilknytning til arbejdsmarkedet. Det er en situation, som mellem 70.000 og 150.000 af deres jævnaldrende allerede befinder sig i. Disse alarmerende tal gør en indsats imod ungdomsarbejdsløshed til en bunden opgave for de nordiske lande.

Selvom den økonomiske krise har gjort arbejdsløshed til et helt centralt politisk fokusområde i de nordiske lande, mangler der nemlig stadig fokus på de grupper, der i forvejen står på kanten af arbejdsmarkedet, som unge, funktionshindrede og seniorer. De har været overset i de senere år, mener i hvert fald folkene bag den nye analyse fra Nordens Velfærdscenter i Stockholm.

De har af Nordisk Ministerråd fået til opgave at belyse og analysere, hvordan disse tre udsatte grupper klarer sig på arbejdsmarkedet i Norden. Resultatet er en øjenåbnende rapport, der allerede nu bliver brugt i forberedelsen til de nordiske statsministres jobtopmøde i Stockholm i maj 2013.

Rapporten konkluderer, at alle de nordiske lande bør være opmærksomme på, at den voksende ungdomsarbejdsløshed, som særligt Sverige og Finland oplever, kan medføre store sociale og økonomiske problemer. De nordiske lande kan samtidig lære af hinandens gode og dårlige erfaringer med at fastholde seniorer på arbejdsmarkedet. Det er vigtigt, fordi de nordiske lande allerede nu er udfordret af demografiske ændringer. Derfor er det nødvendigt for en økonomisk holdbar udvikling, at de nordiske lande bliver bedre til at inkludere og fastholde disse grupper på arbejdsmarkedet. Hvis unge aldrig kommer ind på arbejdsmarkedet, og ældre forlader arbejdsmarkedet tidligere end nødvendigt, bliver demografien en uoverskuelig økonomisk udfordring. 
hed ikke først starter, når den unge ansøger om sociale ydelser. „Det er vigtigt også at være opmærksom på frafald i ungdomsuddannelserne“, siger han. Sammen med sine kolleger har han i inspirationshæftet «Inspiration för inkludering» samlet et udvalg af eksempler på gode løsninger. Eksempelvis skal alle unge arbejdsløse på Island deltage i arbejdsmarkedsorienterede aktiviteter (jobtræning, sommerjobs eller frivilligt arbejde), og resultatet er, at $40 \%$ af de unge derefter starter i enten job, uddannelse eller andre arbejdsrettede aktiviteter.

Bjørn Halvorsen er meget fokuseret på, at indsatsen ikke blot må handle om at opkvalificere de unge. „Det er vigtigt at huske begge sider af arbejdsmarkedet, sådan at man også gør det mindre risikabelt for eksempelvis små virksomheder at tage en chance ved at ansætte og oplære en ung. Det handler selvfølgelig om at sikre nok lærepladser, trainee-stil- linger og lignende, men indsatsen kan også bestå af små ændringer såsom kommunal hjælp til de små virksomheders papirarbejde ved praktikophold eller korte ansættelser“, siger han. En sådan indsats for at gøre det lettere at give flere unge en chance kalder Halvorsen for „en nul-risiko-strategi for virksomhederne“.

\section{Inklusion er en investering}

Ifølge Bjørn Halvorsen er alle de nordiske lande opmærksomme på, at inklusion af flere borgere på arbejdsmarkedet er en langsigtet og nødvendig investering i fremtiden. I maj mødes de nordiske statsministre i Stockholm for at gøre noget ved problemet med ungdomsarbejdsløshed.

Topmødet skal samle forskere, beslutningstagere og praktikere for at skabe et overblik over problemet og for at udveksle erfaringer. Det fortæller Åsa Olli Segendorf, som er økonom i Sveriges Finansdepartement og medansvarlig for det kommende topmøde.

I dette arbejde har Nordens Velfærdscenters arbejde været et vigtigt grundlag. „Konkret har vi brugt rapporten som et læringsgrundlag i arbejdet med at udpege de vigtigste problemstillinger for topmødet“, fortæller Segendorf, der i øjeblikket indsamler den mest relevante viden til topmødets diskussioner. Bjørn Halvorsen er en del af det advisory board, der rådgiver i dette arbejde.

\section{Seniorer skal fastholdes}

Der er særligt én gruppe, som de nordiske lande deler en række smertelige erfaringer med, fortæller Bjørn Halvorsen. Det er seniorerne: „For 20 år siden forsøgte de nordiske lande sig med, at seniorerne skulle trække sig tilbage for at give plads til de unge. Det virkede ikke, og det har tilmed været svært at ændre igen“. De nordiske lande har taget ved lære af erfaringerne, og fokus er nu i stedet 


\section{Arbejdsinkluderingsprojektet}

1

på at fastholde ældre medarbejdere på arbejdsmarkedet.

Halvorsen og hans kolleger satte sig derfor for at undersøge, hvad der får seniorerne til at trække sig tilbage fra arbejdsmarkedet. Det er blevet til en kortlægning af de primære veje ind i pensionen. Eksempelvis bruger forskerne betegnelsen „sundhedsvejen“ om de seniorer, der på grund af svigtende helbred eller arbejdsulykker må forlade arbejdsmarkedet, før de ønsker det. „Helbredsproblemer er stadig den vigtigste årsag til tilbagetrækning, og det betyder, at man ikke kan fastholde alle ældre kun ved hjælp af pensionsreformer“, siger Bjørn Halvorsen. Han pointerer dermed, at et fokus på forebyggelse af sundhedsproblemer og arbejdsulykker også er nødvendigt, og her kan de andre lande lære af Finland.

Finland har nemlig i over 30 år arbejdet fokuseret på at forebygge seniorers tidlige tilbagetrækning på grund af helbredsmæssige årsager. Professor Juhani Ilmarinen har været med hele vejen, og han har forsket i fastholdelse af seniorer på det finske arbejdsmarked. I øjeblikket rådgiver han tre forskellige europæiske regeringer på baggrund af de finske erfaringer, og han tøver ikke med at give sit vigtigste råd: „Det vigtigste er at fokusere på det positive først og det negative senere. Sørg for, at ansatte kan, vil og får mulighed for at arbejde længere“, siger han.

Ifølge Ilmarinen skyldes finnernes succes et vedvarende politisk fokus. Fastholdelse af seniorer er samtidig en nødvendighed, fordi landet har den største babyboom-generation i hele Europa. „Derfor er det et område, vi har arbejdet med siden starten af 1980'erne, og det er netop kontinuitet i og konsensus om indsatsen, der har været den vigtigste succesfaktor“, fortæller han.
Også andre skandinaviske lande har dog gjort sig vigtige erfaringer. Nordisk Velfærdscenter bruger betegnelsen „fritidsvejen“ om dem, der frivilligt vælger at forlade arbejdsmarkedet for at få bedre tid til andre ting. På dette område er Danmark gået $\mathrm{i}$ front ved at reformere pensions-systemer og ændre incitamentsstrukturerne, så det er blevet langt mere fordelagtigt at blive længere på arbejdsmarkedet.

„Mennesker er forskellige, og det er de naturligvis også, når de bliver ældre. Derfor har vores arbejde heller ikke givet grund til at tænke i one-size-fits-all-tiltag“, forklarer Bjørn Halvorsen, der da også advarer imod at tro, at man i seniorpolitikken kan opnå det ønskede resultat ved at dreje på et enkelt håndtag.

\section{Effektforskning efterlyses}

Et af projektets anbefalinger er, at der gennemføres en række effektstudier af de nordiske landes forskellige 
tiltag for at inkludere de særlige grupper på arbejdsmarkedet. Det vil kunne give et langt mere specifikt billede af, hvilke tiltag der virker, end vi har i dag. „Vi er gode til effektforskning i Norden, ikke mindst fordi vi har så gode registre. Men vi har brug for mere af den slags forskning, hvis vi vil vide, hvilken nytte et tiltag rent faktisk gør“, siger Bjørn Halvorsen.

Åsa Olli Segendorfs research peger i samme retning: „Vi ved en masse om, hvordan situationen er i dag, men ikke ret meget om, hvad der kan ændre den“, konstaterer hun tørt.

Rapporten inkluderer en række eksempler på best practice i de nordiske lande, og med baggrund i rapporten er der taget initiativ til en online-idébank, hvor sådanne eksempler kan samles, fortæller Bjørn Halvorsen, inden han fortsætter: „Det handler om at stille viden til rådighed, så beslutningstagerne har mulighed for at se de forskellige løsninger, som andre nordiske lande har forsøgt sig med“.

Dermed er bolden spillet tilbage på politikernes banehalvdel, inden de mødes i Stockholm i maj 2013 til jobtopmødet under det svenske formandskab.

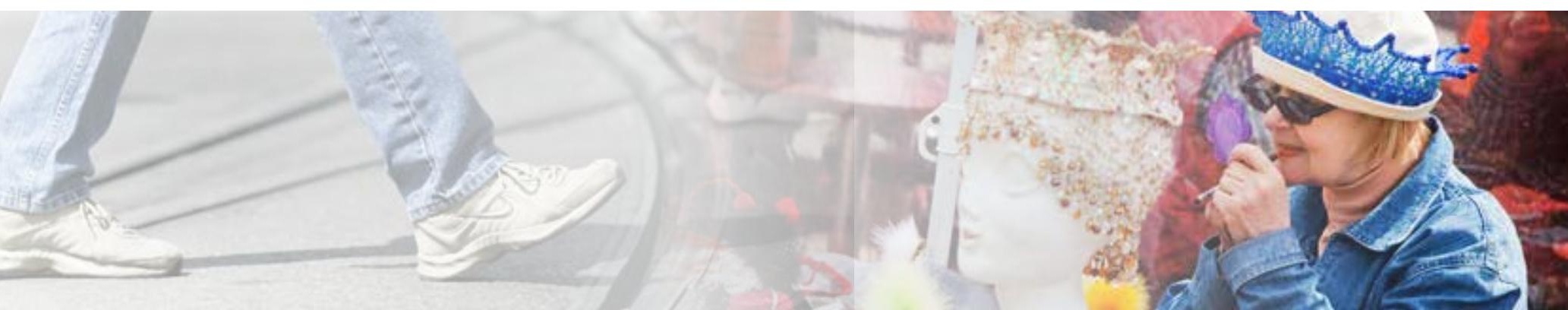


„Problemet er, at disse arbejdere ofte ikke får den løn, som danskere, nordmænd og islændinge får i de pågældende jobs. Derfor står vi med en situation, som fører til et lønpres i sektorer for lavt uddannede“.

Søren Kaj Andersen 


\section{Arbejdsindvandring afslører den nordiske models blinde pletter}

\section{Hovedpointer}

- Ny komparativ analyse af polske gæstearbejderes vilkår i Danmark, Island og Norge giver et unikt indblik i løn- og arbejdsforhold og viser styrker og svagheder ved de nordiske landes forskellige indretninger af arbejdsmarkedet. Undersøgelsen viser samtidig, at de nordiske lande kan lære af hinandens erfaringer.

- De polske arbejdere făr ikke den Łøn, som danskere, nordmænd og islændinge får i de pågældende jobs. Derfor står vi med en dumping-situation, siger en ekspert på baggrund af undersøgelsen, der blandt andet dokumenterer, at polakker i Norden arbejder for helt ned til 24 DKK i timen.

- Både fagbevægelsen og forskere advarer mod de langsigtede risici og en stor efterregning til staterne, hvis ikke gæstearbejderne bliver inkluderet på det organiserede arbejdsmarked.
Da 10 nye lande i 2004 trådte ind i EU, var der i det gamle EU frygt for en stor indvandring af billig arbejdskraft fra Østeuropa. Bekymringen var særlig stor i de nordiske lande, hvor traditionen for et højt lønniveau og særlige aftaler mellem arbejdsmarkedets parter forhøjer risikoen for et parallelt arbejdsmarked og social dumping.

I dag, næsten 10 år senere, tegner der sig et klart billede af, at store grupper af østeuropæiske gæstearbejdere arbejder i de skandinaviske lande i kortere og længere perioder. Fagbevægelsen har ikke været sen til at gøre opmærksom på, at dette i mange sektorer sker på irregulære vilkår, som medfører et stigende lønpres.

Alligevel findes der kun få sammenlignende undersøgelser af konsekvenserne for det nordiske arbejdsmarked. Det har derfor ikke tidligere været muligt at tegne et samlet billede af gæstearbejdernes løn- og arbejdsvilkår. Det råder Fafo, et af Norges største forskningsinstitutter, nu bod på. Fafo har ledt dette nye projekt, som i samarbejde med andre nordiske forskningsmiljøer skitserer de store udviklingstræk i arbejdsmigrationen og zoomer specifikt ind på vikarbureauernes rolle.

\section{Lønforskellene skaber ubalance}

Først og fremmest er det vigtigt at forstå, hvorfor netop denne EUudvidelse er en særlig udfordring for de nordiske arbejdsmarkeder. „Den nuværende arbejdsindvandring er langt større end det, vi har oplevet tidligere, for der kom der for eksempel aldrig store grupper af portugisere og spaniere, da disse lande blev medlem af EU“. Det siger Søren Kaj Andersen, lektor på Københavns Universitet og leder af Forskningscentret for Arbejdsmarkeds- og Organisationsstudier (FAOS), som forklaring på, hvorfor EU-udvidelsen har medført nye udfordringer. FAOS er den danske partner i projektet, og 
i Oslo, København og Reykjavik. Det er disse data, som Line Eldring og hendes kolleger nu har haft mulighed for at analysere til bunds.

Søren Kaj Andersen byder analysen velkommen og gør opmærksom på vigtigheden af den nye viden. „Dette projekt er den vigtigste forskning på området“, siger han og understreger samtidig betydningen af at sammenligne de nordiske landes erfaringer.

Ved at undersøge løn- og arbejdsforhold for de polske arbejdere bliver det nemlig tydeligt, hvordan de nordiske landes forskellige arbejdsmarkedspolitikker giver forskellige udfordringer og succeser. „Det, der betyder meget for gæstearbejdernes løn- og arbejdsforhold, er de nationale arbejdslivsregimer", siger Line Eldring. Det er med andre ord ikke så meget gæstearbejdernes kvalifikationer, men de nordiske landes organisering af deres arbejdsmarkeder, som bestemmer de polske arbejderes vilkår.

Polske arbejdere i Norden får mindre i løn end lokale

\begin{tabular}{l|c|c|c} 
& Island & Norge & Danmark \\
\hline Gennemsnitlig timeløn & 1203 ISK & 142 NOK & 116 DKK \\
\hline $\begin{array}{l}\text { Gennemsnitsløn i procent af } \\
\text { nationalt gennemsnit }\end{array}$ & 57 & 65 & 85 \\
\hline Mindste timeløn angivet & 532 ISK & 30 NOK & 24 DKK \\
\hline Højeste timeløn angivet & 3721 ISK & 372 NOK & 257 DKK \\
\hline Antal respondenter (N) & 231 & 289 & 442 \\
\hline
\end{tabular}

Tabel 1: Løn-data på polske arbejdere i Reykjavik, Oslo og København.

Kilde: Fafo, 2013

\section{Store forskelle mellem de nordiske lande}

Ved at sammenligne de nationale arbejdsmarkedsmodeller med landenes resultater bliver forskellene tydelige. Norge har siden 1994 haft en lov, der gør det muligt at almengøre overenskomster på områder eller i brancher, der er truet af social dumping. Hvis en overenskomst bliver almengjort, skal arbejdsgiverne følge overenskomsten på det givne område, og det har forbedret forholdene for mange gæstearbejdere. På Island almengøres de fleste overenskomstaftaler, mens det i dag blot er fire aftaler, som er almengjort i Norge.

Danmark har modsat Norge og Island fastholdt, at forholdene på arbejdsmarkedet ikke skal bestem- 


\section{Store forskelle i Norden}

\begin{tabular}{l|c|c|c} 
(2009) & Danmark & Island & Norge \\
\hline $\begin{array}{l}\text { Medlem af fagforening, pct. af } \\
\text { arbejdstagere }\end{array}$ & 67 & 85 & 52 \\
\hline $\begin{array}{l}\text { Dækket af overenskomst, pct. af } \\
\text { arbejdstagere }\end{array}$ & 80 & 99 & 72 \\
\hline $\begin{array}{l}\text { Almengørelse af overenskomst- } \\
\text { bestemmelser ved lov }\end{array}$ & Nej & $\begin{array}{c}\text { Ja, } \\
\text { udbredt }\end{array}$ & $\begin{array}{c}\text { Ja, til en } \\
\text { vis grad }\end{array}$
\end{tabular}

\section{Tabel 2}

Kilde: Nordic labour market institutions and the incorporation of new migrant workers. Eldring et al., 2013

mes af staten. Det har ført til store lønforskelle mellem de arbejdere, der arbejder under overenskomst, og dem, der arbejder uden for.

Island kan prale af den klart højeste organiseringsgrad blandt immigrantarbejderne, hvilket generelt har sikret de bedst regulerede arbejdsforhold. Se tabel 2. Til gengæld tillader de islandske overenskomster så store lønforskelle, at de polske arbejdere på Island tjener klart mindst - både i forhold til det lokale lønniveau og i absolutte tal i forhold til deres landsmænd i Danmark og Norge.

\section{Se tabel 1.}

Line Eldring konkluderer, at den nye analyse ikke kan pege på den perfekte løsning, men i stedet understreger styrker og svagheder ved alle tre landes tilgange. „Man kan sige det sådan, at tilstrømningen af østarbejdere har synliggjort nogle sårbare punkter i vores respektive arbejdslivsreguleringer“, konstaterer hun.

\section{Fagbevægelsen efterspørger mere viden på området}

Gunde Odgaard repræsenterer arbejderne i anlægs- og byggesektoren i Danmark. Han hilser undersøgelsen velkommen. „Jeg kan bruge sådan en undersøgelse til at blive klogere på, hvad de udenlandske arbejdstagere tænker og føler. Vi er i den danske fagbevægelse blevet rigtig gode til at køre arbejdsretslige sager og hjælpe vores medlemmer, men vi skal blive bedre til at inkludere udenlandske arbejdstagere“, siger Odgaard.

Selvom de nordiske lande har forskellige erfaringer, er landene i udgangspunktet så ens, at de med fordel kan inspirere hinanden. „På dette felt har de nordiske lande ekstremt stor nytte af at udveksle erfaringer“, siger Line Eldring. Det mærker hun også, når hun fortæller beslutningstagere i embedsværket og hos arbejdsmarkedets parter om resultaterne. „Det er mit indtryk, at der er en meget stor interesse for

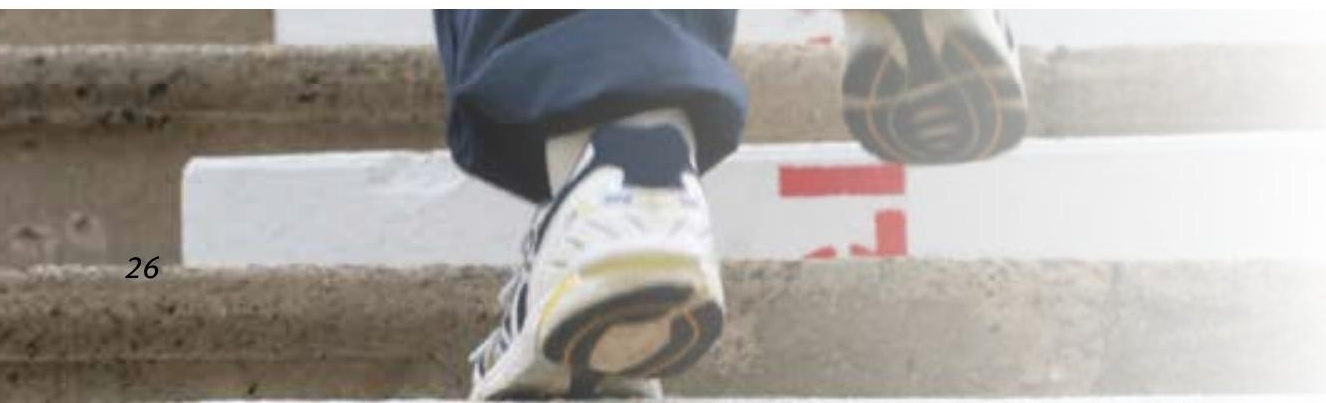


"Vi er i den danske fagbevægelse blevet rigtig gode til at køre arbejdsretslige sager og hjælpe vores medlemmer, men vi skal blive bedre til at inkludere udenlandske arbejdstagere“.

Gunde Odgaard 
ny viden om udenlandsk arbejdskraft i Norden. Det gælder ikke bare vores projekt, men også andre initiativer, der undersøger udviklingen på arbejdsmarkedet i Norden“, siger Eldring.

\section{Vikarindustrien ansætter udenlandsk arbejdskraft}

Fafo og de nordiske forskningspartnere har som en del af projektet også lavet sammenlignelige opgørelser over, hvor mange gæstearbejdere der er taget til landene i Norden. Det har tidligere været problematisk, fordi landene benytter vidt forskellige registermetoder.

De nye opgørelser viser, at indvandringen til Norden er styret af efterspørgsel, hvilket også er grunden til, at vikarindustrien er vokset i de seneste år. Forskerne har specifikt undersøgt vikarindustriens rolle i den $\emptyset$ gede arbejdsindvandring. Konklusionen er, at industrien ikke af sig selv driver arbejdsindvandringen frem, men at det afgørende er de store forskelle i reguleringer og efterspørgslen efter arbejdskraft. Vikar- og rekrutteringsbureauerne er populære, fordi de „billigt og effektivt formidler kvalificeret udenlandsk arbejdskraft, hvilket er dyrt og besværligt for de enkelte firmaer i de nordiske lande“, fortæller hun.

I et land som Norge har industrien ganske vist været medvirkende til en øget indvandring, men det skyldes ifølge forskerne i langt overvejende grad den store efterspørgsel på arbejdskraft i landet, som bureauerne har bidraget til at finde en løsning på. Modsat er den islandske rekrutteringsindustri efter krisen nærmest ikkeeksisterende, og der foregår i øjeblikket en fraflytning af østeuropæisk arbejdskraft fra Island.

Arbejdsvandringerne følger økonomiske konjunkturer og ændrede rammevilkår, og det giver ikke bare udfordringer for forskningen, men også for reguleringen. „Denne meget mobile arbejdskraft, som i skiftende mønstre kommer og arbejder i kortere eller længere perioder, er meget svær at kontrollere. Det stemmer jo fint overens med princippet om at ville skabe et fælleseuropæisk indre marked, men det giver nogle reguleringsudfordringer, der stadig er et nationalt anliggende“, opsummerer Søren Kaj Andersen.

\section{De nordiske lande risikerer en stor regning på langt sigt}

Særligt gruppen af udstationerede medarbejdere giver problemer for både arbejdsmarkedsopgørelser og lovgivning, da medarbejderne så kan forblive under hjemlandenes regulering. Sådanne arbejdsforhold vil sandsynligvis blive endnu mere udbredt i de kommende år. „En øget brug af udstationering kan blive et problem, for det er en ansættelses- 
form, som hidtil har givet klart dårligere vilkår for de ansatte. Flere i Norden frygter derfor, at udviklingen går i retningen af flere fiktive underentrepriser", advarer Line Eldring. Hun får opbakning af Gunde Odgaard, der også kan genkende billedet. „Der er ganske vist nogle krav, der skal følges, før man må udstationere arbejdere, men vi kan se, at de ikke bliver fulgt", siger han.

På kort sigt kan arbejdsindvandringen være en rigtig god forretning for virksomhederne, men forskningen viser også, at de løse ansættelser gennem eksempelvis vikarbureauer meget sjældent fungerer som en genvej til regulær ansættelse. „Man kan se, at store grupper af migranter forbliver i atypiske jobs og derfor ikke etablerer en ordentlig tilknytning til arbejdsmarkedet i en regulær ansættelse“, siger Line Eldring. Derfor er der en risiko for, at de nordiske lande på længere sigt ender med en stor regning: „Selvom disse arbejdere gennemsnitligt får langt lavere løn, kan det blive til en stor regning på langt sigt, hvis arbejderne optjener retten til velfærdsydelser", siger hun. Søren Kaj Andersen gør opmærksom på risikoen for en anden utilsigtet konsekvens. „Vi ved eksempelvis ikke nok om, hvad der i disse år sker med uddannelsen af lærlinge, når de store byggepladser bare henter udenlandsk arbejdskraft ind, og der ikke bliver uddannet nye lokale håndværkere“, siger han. Dette bekymrer også Gunde Odgaard. „Vi skal huske på, at byggesektoren kun aftager halvdelen af de lærlinge, vi uddanner, så blandt andet industrien kommer hurtigt til at mangle tømrere og elektrikere, hvis ikke byggesektoren uddanner nok lærlinge“, påpeger han.

Derfor peger begge forskere på, at projektet rejser en lang række nye spørgsmål, som der skal arbejdes videre på. Line Eldring har eksempelvis efterfølgende publiceret en rapport om, hvordan arbejdstilsyn i Norden håndterer social dumping. „Vi kigger også på fagbevægelsernes forskellige tilgange, og det er noget, der bliver læst med stor interesse“, siger Line Eldring.

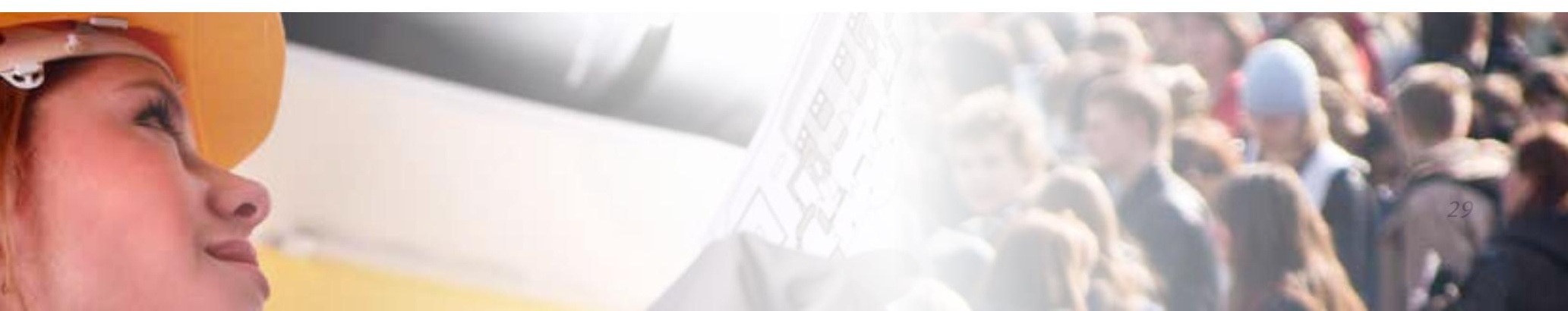


„Hvis virksomhederne ikke tænker sig om, går de potentielt glip af højt kvalificeret arbejdskraft, fordi de ikke bliver opmærksomme på de barrierer, disse grupper har“. Per Kongshøj Madsen 


\section{Nordiske vækstvirksomheder efterlyser konkurrencedygtig arbejdskraft}

\section{Hovedpointer}

- Voksende virksomheder i Norden efterspørger først og fremmest adgang til konkurrencedygtig, kompetent og fleksibel arbejdskraft. Det er konklusionen på en ny undersøgelse af de nordiske virksomheder, som skaber nye jobs og samtidig er blandt de mest produktive i deres branche.

- De succesfulde virksomheder kan forbedre sig yderligere, hvis de bliver mere opmærksomme på de særlige barrierer for kvinder og seniorer på arbejdsmarkedet.

- I et særligt policyforum bestående af embedsmænd, forskere, arbejdsmarkedsorganisationer og virksomheder har projektet udviklet en række anbefalingerne til bedre rammevilkår for erhvervslivet. De er samlet i et inspirationskatalog, der giver ideer til både beslutningstagere og virksomheders indsatsområder.
De nordiske virksomheder møder stadig hårdere international konkurrence i en globaliseret verden, der er præget af stor mobilitet. Det stiller store krav til virksomhedernes konkurrencedygtighed, hvis de også fremover skal kunne skabe jobs i Norden. For at fjerne unødige forhindringer for erhvervslivet har Damvad stået i spidsen for et forskerkonsortium, som har gennemført en stor analyse, der kvalitetstester de rammevilkår, virksomhederne arbejder under.

Analysen undersøger virksomheder, som evner at kombinere jobskabelse med at være blandt de mest produktive virksomheder på deres felt. „Konkurrencedygtige jobskabere“ kalder Damvad dem. „Disse virksomheder er ekstra interessante, for de skaber de jobs, der er økonomisk bæredygtige, og det er dem, vi skal leve af i fremtiden“, siger Lars Foldspang, der som projektleder og chefkonsulent ved Damvad har været ansvarlig for projektet.
Jobskabelse sker i alle brancher Analysens tilgang sikrer, at en lang række brancher er repræsenteret. „Ved at udvælge de mest produktive virksomheder i de enkelte sektorer får vi hele spektret af konkurrencedygtige virksomheder med. Ellers ville varierende markedsvilkår i de forskellige brancher gøre, at vi kunne komme til at tro, at Norden kun burde satse på én bestemt type virksomheder“, fortæller Lars Foldspang.

Fokus er på jobskabelse, men vel at mærke i de virksomheder, som allerede er blandt de mest produktive. „De nordiske lande har jo ikke specielt meget ud af, hvis der bliver skabt jobs $\mathrm{i}$ virksomheder, som ikke er i stand til at konkurrere“, som Lars Foldspang siger. „Vi leder efter de virksomheder, der kan tilbyde fremtidens jobs“, siger han.

Efter at have identificeret denne nøglegruppe af virksomheder på baggrund af registerdata blev en række analyser af virksomhedernes fællestræk gennemført. Den giver et grundigt billede

"Det er egentlig synd, at arbejdsmiljø og produktivitet i den gængse forståelse ikke tænkes sammen, for glade medarbejdere arbejder jo hurtigere og hårdere end sure medarbejdere“, Lars Foldspang 


\section{PROJEKT}

\section{De nordiske vækstsektorer: Hvordan kan arbejdslivspolitik- ken bidrage til at forbedre ram- mevilkårene?}

\section{Formål:}

Identificere konkurrencedygtige virksomheder, der skaber nye jobs, og undersøge fælles drivere for deres succes, og hvilke rammevilkår de anbefaler at ændre.

\section{Ansvarlig organisation:}

Damvad, København, Danmark

\section{Projektleder:}

Lars Foldspang, chefkonsulent af, hvilke faktorer de succesfulde virksomheder har til fælles, hvilket kan være opskriften på, hvordan andre virksomheder også kan blive konkurrencedygtige jobskabere.

\section{Virksomheder peger på barrierer for fortsat vækst}

Analysen viser blandt andet, at de succesfulde virksomheder både ansætter højtuddannede medarbejdere, investerer i maskiner, bygninger og lignende, og at de er til stede på udenlandske markeder. En af de vigtige konklusioner er dog, at ikke alle virksomheder har brug for samme medicin. „Vi kan se, at hvis man i forvejen er en virksomhed med relativt høj jobvækst, så virker det godt at investere i immaterielle aktiver såsom software eller patenter, men for de knap så hurtigt voksende virksomheder er det en langt dårligere investering“, siger Lars Foldspang.

Foldspang og hans kolleger har også undersøgt, hvilke rammevilkår de allerede succesfulde virksomheder selv mener, bør ændres, hvis virksomhederne skal gøre det endnu bedre. Derfor er virksomhederne gennem surveys og interviews blevet spurgt om de største barrierer for $ø$ get vækst. Velkendte faktorer som for højt lønniveau, manglende fleksibilitet $i$ ansættelserne og administrative byrder dominerer svarene. De konkurrencedygtige jobskabere vil altså have mere albuerum og adgang til konkurrencedygtig, kompetent og fleksibel arbejdskraft for at kunne investere og skabe flere arbejdspladser. Den vigtigste af alle barrierer er dog manglen på den rette arbejdskraft.

Lars Foldspang anerkender, at flere af temaerne er velkendte, men mener, at afsenderen gør det væsentligt at lytte til budskabet alligevel. „Det er jo de her virksomheder, der skaber fremtidens jobs i Norden, så derfor bør vi lytte nøje til, hvilke barrierer for øget vækst disse virksomheder møder“, siger Foldspang.

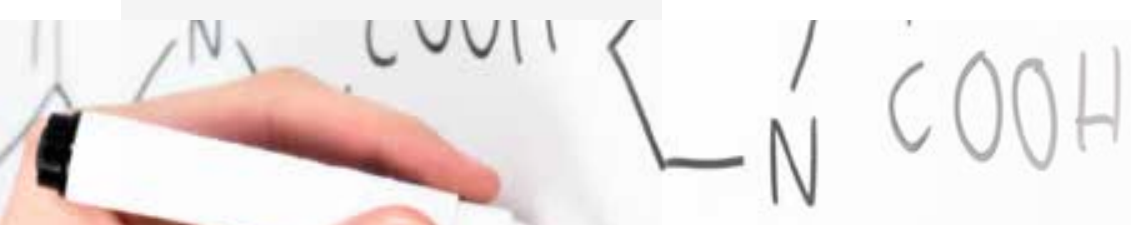




\section{Nordiske vækstvirksomheder efterlyser konkurrencedygtig arbejdskraft}

\section{Virksomhederne glemmer seniorerne og kvinderne}

Per Kongshøj Madsen, professor i økonomi på Aalborg Universitet, er enig. Han har fulgt projektet og understreger de mulige policy-implikationer. „Det er særligt interessant at finde mismatchet mellem de udfordringer, disse virksomheder oplever, og de rammevilkår, de agerer $\mathrm{i}$, for det er netop der, der er potentiale for forbedringer“, siger han.

Virksomhederne i undersøgelsen giver nemlig udtryk for, at det er svært at finde de rette medarbejdere med de rigtige kvalifikationer. Til gengæld er virksomhederne mindre bekymrede over den aldrende arbejdsstyrke. „Deres medarbejderes gennemsnitsalder er omkring 40 år, så virksomhederne er mere bekymrede over, hvor besværligt det er at ansætte udenlandsk arbejdskraft her og nu“, fortæller Lars Foldspang.
Det får en gul advarselslampe til at lyse for økonomen Per Kongshøj Madsen. Den manglende bekymring fører til, at disse virksomheder ikke rigtigt tænker i seniorpolitik. På samme måde er mange af disse ekspanderende virksomheder ikke opmærksomme på en effektiv ligestillingspolitik. „Det er interessant, for en aldrende arbejdsstyrke og højtuddannede kvinder er to af de vigtigste trends på arbejdsmarkedet. Hvis virksomhederne ikke tænker sig om, går de potentielt glip af højt kvalificeret arbejdskraft, fordi de ikke bliver opmærksomme på de barrierer, disse grupper har“, siger han.

\section{Et godt arbejdsmiljø stimulerer vækst}

Forskerkonsortiet har også undersøgt, om de ansatte hos de konkurrencedygtige jobskabere har så travlt, at det får konsekvenser for arbejdsmiljøet. Den gode nyhed er, at arbejdsmiljøet hverken er værre eller bedre end hos en gennemsnitlig nordisk virksomhed.

Derimod peger analysen på, at et forbedret arbejdsmiljø kan være en mulig vækstdriver. „Det er egentlig synd, at arbejdsmiljø og produktivitet i den gængse forståelse ikke tænkes sammen, for glade medarbejdere arbejder jo hurtigere og hårdere end sure medarbejdere“, siger Lars Foldspang.

En af anbefalingerne fra projektet er da også at styrke det i forvejen gode arbejdsmiljø i nordiske virksomheder ved at implementere et arbejdsmiljøbarometer. Lars Foldspang gør opmærksom på, at det ganske vist kan ses som en opgave for de nordiske lande, men han kan også forestille sig, at de nordiske virksomheder selv vil indføre et sådant barometer og benytte det som et værktøj til at tiltrække og fastholde kvalificeret arbejdskraft - og derigennem øge væksten.

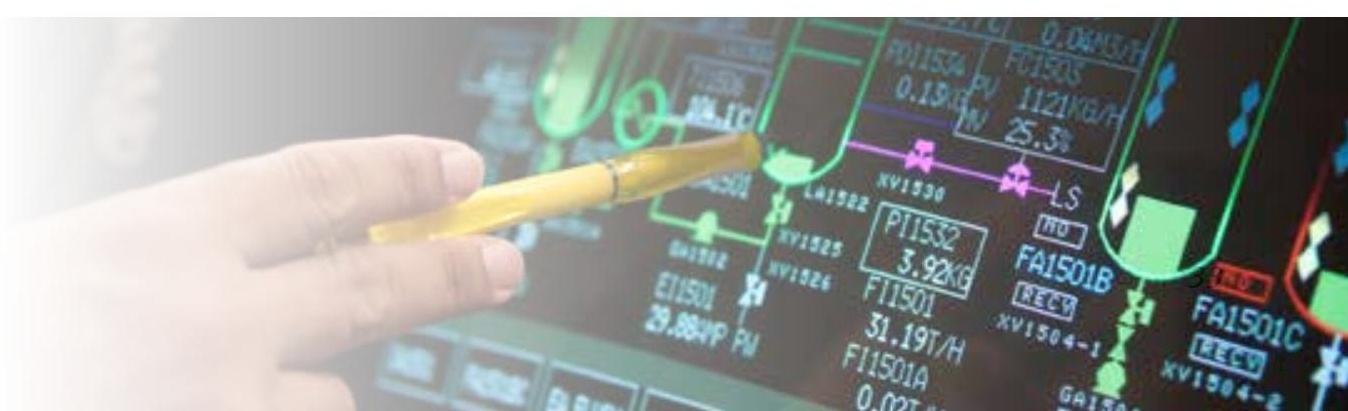


En anden anbefaling fra projektet er, at nyuddannede skal trænes i stresshåndtering i løbet af deres uddannelse. Også her kan pilen dog pege på flere aktører, hvor bedre muligheder for praktikforløb i løbet af uddannelserne er et oplagt redskab. „Virksomheder kan også bruge anbefalingen til at sige, at deres nye medarbejdere ikke er færdige med at blive uddannet, når de starter $\mathrm{i}$ virksomheden. Og det kan bedre betale sig for virksomhederne at investere i træningen af nye medarbejdere i stedet for at vente på, at uddannelserne bliver skræddersyet efter erhvervslivets ønsker“, siger Lars Foldspang.

\section{Lyt til virksomhederne}

Anbefalingerne kommer fra et såkaldt policyforum, hvor beslutningstagere fra regeringer, arbejdsmarkedsorganisationer og virksomheder fra hele Norden har mødtes til konstruktiv diskussion om bedre vilkår for de konkurrencedygtige jobskabere. Resultatet er et inspirationskatalog til aktører med interesse for virksomheders rammevilkår.

Claus Skytte er direktør i kreativitetsbureauet We Love People og repræsenterede på policyforum en af de virksomheder, undersøgelsen har identificeret. „Det var en fornøjelse at bidrage med viden om en verden, som de andre deltagere bedst kendte fra statistikker, og jeg mødte både stor nysgerrighed og lydhørhed“, fortæller han.

Erfaringsudvekslingen har givet forskere og konsulenter indsigt i de barrierer, som virksomhederne dagligt slås med. Per Kongshøj Madsen giver et konkret eksempel fra diskussionerne: „Virksomhederne har brug for højtuddannet arbejdskraft, og blandt andet derfor uddanner vi også udlændinge i Norden. Men vi har ikke et nordisk arbejdsmarked for ikke-europæere. Det betyder, at en kineser, der bliver ph.d. i Danmark, ikke uden videre kan søge job i Norge“, fortæller han.

Der er derfor noget at lære ved at lytte til virksomhedernes erfaringer. Både fordi de er hverdagens eksperter, og fordi det jo i sidste ende er disse virksomheder, der skal finansiere de nordiske velfærdsstater, slutter Lars Foldspang og vender dermed tilbage til undersøgelsens udgangspunkt.

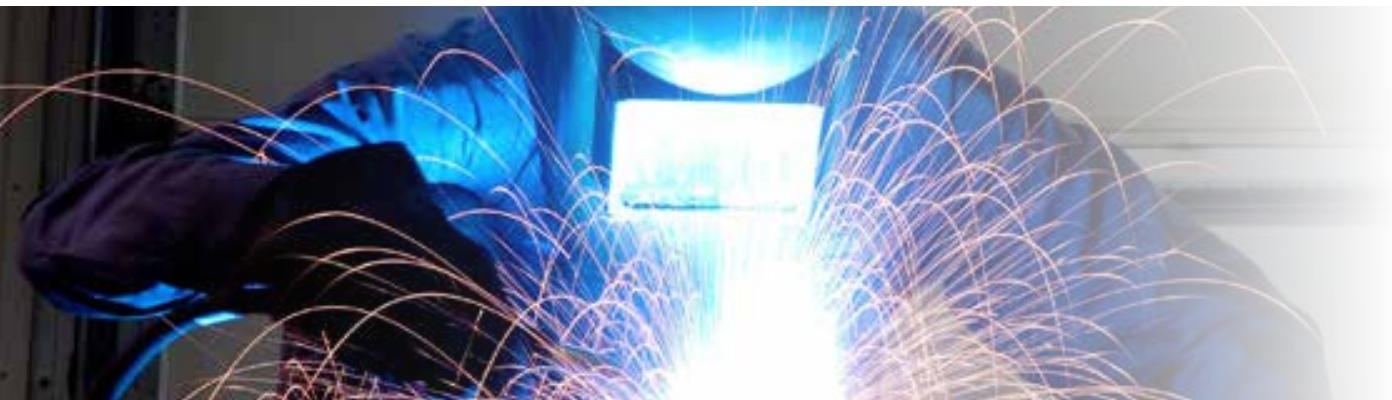


„Det er egentlig synd, at arbejdsmiljø og produktivitet i den gængse forståelse ikke tænkes sammen, for glade medarbejdere arbejder jo hurtigere og hårdere end sure medarbejdere“, Lars Foldspang 
„Det handler i sidste ende om, hvordan man giver familien en mulighed for at tage kontrollen over deres liv, sådan at de bevidst kan træffe de sundhedsmæssige valg, som vil agøre en forskel for deres børn". Antti Uutela 


\section{Hovedpointer}

- Livsstilssygdomme rammer stadig flere og stadig yngre personer. Fordi kost- og motionsvaner for resten af livet grundlægges $i$ barndommen, er det afgørende at sætte tidligt ind.

- Et nyt projekt fra Nordiska Högskolan För Folkhälsovetenskap hjælper forældre med at træffe de sunde valg for deres børn. Det sker gennem et konkret værktøj, der kan bruges til at opkvalificere både forældre og børneprofessionelle.

- Flere kommuner har allerede udvist stor interesse for det nye værktøj, der ved at sætte en gruppe forældre sammen med andre voksne, som spiller en rolle i børnenes liv, kan bidrage til at skabe et stærkt partnerskab omkring børnenes opvækst.
Børnefamilier bombarderes dagligt med information om det sunde liv fra medier, sundhedseksperter og det pædagogiske personale i børnehaver og daginstitutioner. For at hjælpe forældrene med at vælge det væsentlige til og tage kontrollen over deres børns sundhed har Karin Ringsberg, professor på Nordiska Högskolan För Folkhälsovetenskap, stået i spidsen for udviklingen af et nyt nordisk hjælperedskab. Ambitionen er at give forældre til førskolebørn kompetencer til at fremme deres børns sundhed.

Opmærksomheden på børns sundhed er ikke blevet mindre af de mange alarmerende rapporter om folkesundheden i Norden. Med Karin Ringsberg i spidsen tog projektgruppen udfordringen op ud fra en tese om, at udviklingen bedre kan vendes, hvis man faktisk hjælper forældrene med at træffe de sunde valg i stedet for blot at advare dem mod det usunde. Dermed håber udviklerne at kunne påvirke folkesundheden på lang sigt, fordi børns kost- og motionsvaner grundlægges i hjemmet hos forældrene og kommer til at følge dem resten af livet.

Det er blevet til et konkret værktøj, som kan bruges til at opkvalificere både forældre og børneprofessionelle. „Målet er at videreuddanne forældre til at hjælpe deres egne børn. Derfor fokuserer vi de på sundhedsfremmende løsninger, som forældrene selv kan indføre“, fortæller hun.

\section{Familien skal tage kontrol over sundheden}

Karin Ringsberg og hendes kolleger udviklet tre tværsektorielle workshops, som de kalder „Nordiske Livsstilsværksteder“. Ideen er, at de voksne omkring en gruppe børn, altså både forældrene, det pædagogiske personale og sundhedspersonalet, skal deltage. Såvel forældre som personale kan tage initiativet til at afholde en workshop.

Antti Uutela har repræsenteret det finske sundhedsinstitut i projektarbejdet. Han lægger særlig vægt på projektets brug af empowerment-begrebet: „Det handler 


\section{PROJEKT}

\section{Sundhedsfremme og forebyggel- se: intersektorielle workshops}

\section{Formål:}

At udvikle let implementerbare workshops, der lader forældre og børneprofessionelle samarbejde om at øge sundhedskompetencerne i nordiske familier

\section{Ansvarlig organisation:}

Nordiska Högskolan För Folkhälsovetenskap, Göteborg, Sverige

\section{Projektleder:}

Karin Ringsberg, professor emerita i sidste ende om, hvordan man giver familien en mulighed for at tage kontrollen over deres liv, sådan at de bevidst kan træffe de sundhedsmæssige valg, som vil gøre en forskel for deres børn“, opsummerer han.

En workshop er opbygget af små øvelser, der skal starte fælles diskussioner om, hvordan den enkelte forælder, sundhedsplejerske eller pædagog påvirker barnet. Helt konkret er der udarbejdet en hjemmeside med en række arbejdsmaterialer, mødedagsordener, modeller og gode råd.

\section{Førskolebørnene er en overset gruppe}

„Vores fokus er på førskolebørnene, for de har hidtil været en overset gruppe. Det skyldes, at mange tiltag har været rettet mod skolen som arena“, siger Karin Ringsberg. Børnene tilegner sig dog allerede før skolealderen vaner, der kan være bestemmende for deres senere adfærd, og i denne alder er det særligt forældrene, som påvirker børnene.
Antti Uutela er glad for det skarpe fokus på førskolebørn og understreger, at indsatsen kan mindske sociale forskelle. „Det er en meget vigtig faktor for børnenes sundhed, om familien er velfungerende. Derfor er det vigtigt, at vi sætter tidligt ind, sådan at alle børn får bedre opvækstvilkår“, siger han.

Dermed er det forhåbningen, at de udviklede workshops kan give ressourcesvage familier bedre redskaber og kompetencer til at leve sundere, sådan at disse børn ikke allerede ved skolestarten har en væsentligt ringere sundhed end børn fra de ressourcestærke familier.

\section{Styrk partnerskabet omkring familien}

At fremme sundhedskompetencerne i familierne er en opgave, som kun kan løses, hvis man forstår en børnefamilies hverdag. Derfor skal de børneprofessionelle samle en gruppe forældre og bistå dem med at lære af hinandens erfaringer. „Ideen er, at forældre skal mødes med pædagoger og sundhedspersonalet for at diskutere hverdagen, og hvad de kan gøre hjemme i deres egen familie for at fremme barnets sundhed“, fortæller Karin Ringsberg. Projektet fokuserer derfor ikke kun på forældrene, men også på at hjælpe an- 


\section{Mange personer har betydning for børns sundhed}

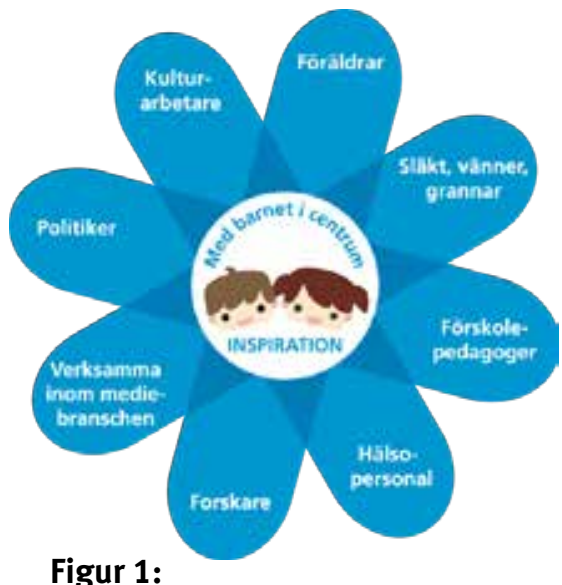

Kilde: www.nordiskalivsstilsverkstan.com

dre voksne i barnets liv med at bibringe barnet sunde vaner. Til det formål er der i forbindelse med projektet lavet en kortlægning af aktører omkring barnet. Se figur 1.

Antti Uutela påpeger, at det ikke kun er forældrene, der kan blive klogere af at deltage på de udviklede workshops. „Ved at give det pædagogiske personale feedback fra forældrene kan de professionelle også blive klogere på, hvordan deres arbejde med barnet fungerer. Dermed bliver de tre workshops til fælles læringsoplevelser for både forældre og personale“, siger han.

Bagtanken med at sætte en gruppe forældre sammen med de andre voksne, som spiller en rolle i børnenes liv, er samtidig at bidrage til skabelsen af et stærkt partnerskab omkring børnenes opvækst. „Der er ikke nogen

\section{Forældre får hjælp til at fremme børnenes sundhed}

bedre måde at bygge partnerskaber på end ved at lade folk samarbejde på lige vilkår om konkrete opgaver“, siger Antti Uutela, der har en baggrund i socialpsykologi.

Det handler altså ikke bare om at udveksle viden på de udviklede workshops, men også om at fremme en indbyrdes forståelse og dialog, som kan forbedre mere end bare den fysiske sundhed for børnene. „Det kan være et problematisk partnerskab, fordi både forældre og det pædagogiske personale mener, at de er eksperter i forhold til barnet. Mens forældrene kender deres eget barn bedst, ser personalet på barnet med sin ekspertviden. Det er netop ved at facilitere oversættelsen mellem disse sprog, at de udviklede workshops gennem gensidig inspiration og dialog kan bidrage til et bedre samarbejde mellem skole og hjem“, siger Antti Uutela.

\section{Stor interesse for at bruge workshops}

Det valgte fokus på at fremme kompetencerne til at vælge en sund livsstil finder opbakning i både forskningslitteraturen og i WHO's arbejde. Her er health literacy der kan oversættes til sundhedsforståelse, et vigtigt begreb og en tilgang, som forskere ser et stort potentiale i. Antti Uutela mener, at de udviklede workshops' styrke er i deres praksisnære brug af disse diskussioner. „WHO-begreber som dette er vanligvis abstrakte idealer, men i dette projekt bliver health literacy oversat og anvendt i en hverdagssituation“, siger han. Allerede nu er der interesse for at gøre brug af de nyudviklede workshops: „To kommuner har allerede vist interesse for at arbejde med modellen. Så nu handler det om at få konceptet prøvet af, få tilbagemeldinger fra brugerne og videreudvikle materialet derfra“, siger Karin Ringsberg, der i første omgang særligt vil fokusere på at videreudvikle de pædagogiske elementer. På sigt forestiller hun sig, at man kan udvikle endnu flere workshops, og de næste tre er allerede på tegnebrættet.

Antti Uutela er enig i prioriteringen. „Det vigtigste nu er at få de tre workshops implementeret. Her spiller det en vigtig rolle at få materialet promoveret, og jeg overvejer i øjeblikket, hvordan jeg bedst kan bidrage til det“, siger han. De udviklede workshops findes allerede på www.nordiskalivsstilsverkstan.com, hvor de kan hentes på både de nordiske sprog og på engelsk, så både forældre, pædagoger og sundhedspersonalet omkring børnefamilier kan se materialet og lade sig inspirere. 
„Vi ved, at hvis man ikke tidligt har lært sig gode madvaner, såsom at spise frugt og grøntsager, så er man mere udsat for at blive overvagtig eller komme til at lide af en livsstilssygdom senere i livet“. Agneta Hörnell 


\section{Fællesnordiske målinger bidrager til bedre kost- og motionsvaner}

\section{Hovedpointer}

- I perioden 2000-2008 steg sundhedsudgifterne i den vestlige verden dobbelt så hurtigt som resten af økonomien. En af årsagerne er flere livsstilssygdomme forårsaget af usund kost og mangel på motion.

- Et nyt projekt forsøger at vende udviklingen ved at fremme bedre kost- og motionsvaner. Det skal ske ved hjælp af et simpelt monitoreringsværktøj, der kan undersøge kost- og motionsvaner i de nordiske lande.

- Værktøjet giver kommuner og andre myndigheder mulighed for at lave billige effektmålinger af deres initiativer og letter spredningen af best practice.
Kun 8 pct. af de nordiske børn spiser en tilstrækkelig sund kost. Samtidig spiser både voksne og børn for få grøntsager og for lidt frugt, kun nordmændene og islændingene spiser fisk ofte nok, og vi indtager alle for meget sukker. Og som om det ikke var nok, så har ingen af de nordiske lande præsteret at få børn til at bevæge sig den anbefalede time om dagen.

Det er det forstemmende resultat af den første fællesnordiske undersøgelse af kost- og motionsvaner, som forskere på Danmarks Tekniske Universitet (DTU) i samarbejde med nordiske kolleger har gennemført. I alt 11.500 personer i Danmark, Norge, Sverige, Finland og Island er blevet spurgt om deres indtagelse af udvalgte fødevarer, deres fysiske aktivitetsvaner og deres vægt.

Undersøgelsen bekræfter det billede af folkesundheden, som et utal af rapporter har peget på. I perioden 2000-2008 steg sundhedsudgifterne i den vestlige verden faktisk dobbelt så hurtigt som resten af økonomien. En af årsagerne er flere livsstilssygdomme forårsaget af usund kost og mangel på motion.

De mange rapporter med forskellige metoder har dog også gjort det svært at sammenligne udviklingstendenserne, og det er det, som den nye fællesnordiske undersøgelsesmetode skal råde bod på. De mange metoder begrænser nemlig ikke bare overskueligheden, men også mulighederne for at evaluere og måle effekten af enkelte tiltag. Problemet er, at enkeltstående projekter mangler en fælles referenceramme at måle deres resultater op imod. Derfor er alle evalueringer i dag nødt til at inkludere en referencegruppe, og det øger omkostningerne ved effektmålinger betragteligt.

Derfor har Fødevareinstituttet på DTU udviklet et nyt monitoreringsværktøj, der kan undersøge kost- og motionsvaner i de nordiske lande. Projektleder ved DTU, seniorrådgiver Sisse Fagt har igennem hele projektet haft fokus på anvendeligheden af det nye analyseværktøj. „Det
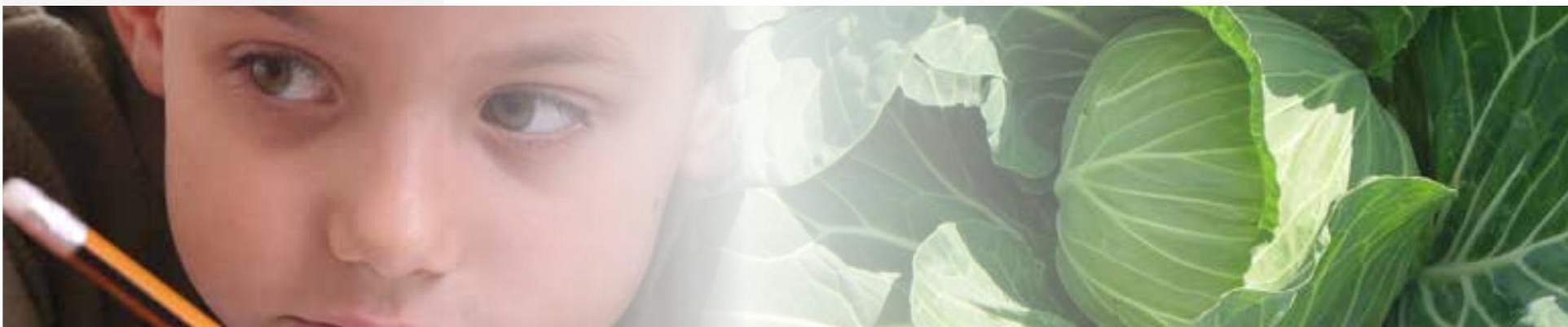


\section{PROJEKT}

\section{Nordisk monitorering af kost, fysisk aktivitet og overvægt}

\section{Formål:}

At udvikle et fællesnordisk værktøj til monitorering af kost- og motionsvaner

\section{Ansvarlig organisation: \\ Fødevareinstituttet, Danmarks Tekniske Universitet, Lyngby, Danmark}

\section{Projektleder:}

Sisse Fagt, seniorrådgiver her er ikke verdensfjern forskning, men handler om at levere et enkelt og billigt værktøj, der virker“, siger hun.

\section{Metoden bruges allerede}

Sisse Fagt glæder sig til resultaterne af næste dataindsamling, der vil gøre det muligt at undersøge udviklingstendenserne. Hun er sikker på, at en fællesnordisk kortlægning af ændringer i befolkningernes vaner vil være interessant for både forskere, praktikere og beslutningstagere.

Resultaterne er en vigtig del af den fællesnordiske handlingsplan for kost og motion, der skal understøtte de enkelte nordiske landes indsats for at fremme sunde kostvaner og fysisk aktivitet samt forebygge overvægt. Fokus er at støtte de tiltag, der giver „en nordisk merværdi for de enkelte lande“, altså de fællesnordiske initiativer, som supplerer landenes nationale indsatser. Merværdien ved fællesnordiske målinger er, at de enkelte lande kan sammenligne deres resultater med fællesnordiske udviklingstendenser.

Sisse Fagt ser dog også store anvendelsesmuligheder for værktøjet her og nu. „Vi skulle gerne have metoden ud over rampen på det nationale og kommunale plan, sådan at eksempel- vis kommuner kan bruge metoden til at måle sig op imod andre kommuner, landsresultater og de nordiske gennemsnit“, siger hun.

ProMeal-projektet, der undersøger effekten af skolemadsordninger i de nordiske lande, se projekt 6 , bruger værktøjet til præcis dette. „Dette værktøj er præcis det, vi ledte efter, for med det får vi både en simpel og billig metode til at måle kostvanerne hos skolebørn, og samtidig får vi en omfattende baseline-gruppe, som vi kan sammenligne vores resultater med“, siger Ingibjörg Gunnarsdóttir, professor i ernæringsvidenskab ved Island universitet, der står for den islandske del af ProMeal-projektet.

\section{Mange aktører kan bruge værktøjet}

Det er netop anvendelsen af værktøjet til at holde en mindre målgruppe op imod de store udviklingstendenser, som Sisse Fagt ser et stort potentiale i. „Vi håber, at både forskere, kommuner og andre vil tage værktøjet til sig som et billigt og nemt supplement til dyrere og mere omfattende analysemetoder", siger hun.

For Ingibjörg Gunnarsdóttir har udgiftsspørgsmålet også spillet en rolle. „Vi vurderede simpelthen, at pengene ville 


\section{Fællesnordiske målinger bidrager til bedre kost- og motionsvaner}

være mere fornuftigt brugt, hvis vi, i stedet for at sætte komplekse og udgiftstunge undersøgelser i gang, benyttede os af dette simple, validerede og allerede oversatte værktøj, der kan løse vores behov“, siger hun.

Konkret består værktøjet af en guide til et kort telefoninterview, som kan gennemføres på 10-15 minutter. Spørgsmålene baserer sig på en række indikatorer på kost- og motionsvaner og er holdt i et letforståeligt hverdagssprog. Sisse Fagt giver et eksempel: „Vi spørger eksempelvis, hvor ofte respondenten spiser pølse, for det kan vi bruge som indikator på, hvor ofte den pågældende spiser fed mad“.

\section{Fællesnordiske undersøgelser fremmer indsatsen}

En fællesnordisk undersøgelse er som nævnt blevet gennemført med metoden i 2011, og der er både planer om og finansiering til at gennemføre den igen i 2014. Første runde har ikke givet de store overraskelser, men det ser udviklerne som et godt tegn, fordi det viser, at de simple spørgsmål kan måle det samme som dyrere og mere tidskrævende analyser.

Selvom analyseværktøjet er simpelt, ligger der grundige overvejelser bag udvalget af spørgsmål. De baserer sig på en svensk spørgeskemaundersøgelse, der er tilrettet og udvidet, så den kan fungere i en fællesnordisk kontekst. Det viste sig faktisk at være lettere, end forskerne havde forventet: „Vi fandt ud af, at selvom vi i de nordiske lande har forskellig kost, kan vi alligevel godt måle kostvaner på tværs af landene“, siger Sisse Fagt.

For at sikre videnskabeligheden, blev spørgeskemaet valideret ved at lade en række respondenter besvare både det nye værktøjs spørgsmål og de fra en mere omfattende, videnskabeligt gennemtestet metode. En sammenligning af konklusionerne fra de to undersøgelser gav forskerne mulighed for at sikre sig, at spørgeskemaets indikatorer måler det rigtige.

Hovedkonklusionen er, at det nye værktøj måler kost- og motionsvaner tilfredsstillende. En gruppe volder dog problemer. Det er de unge. „Det virker ikke til, at de unge kan svare helt realistisk på, hvor ofte de spiser det ene eller det andet“, siger Sisse Fagt.

Til gengæld har valideringen vist, at værktøjet kan bruges i alle de nordiske lande. Dermed er vejen banet for sammenligninger på tværs af grænserne.
Det er vigtigt, for Norden tilbyder i forvejen et unikt miljø til sådanne undersøgelser, da vi i kultur og vaner minder meget om hinanden. Samtidig har de enkelte kommuner, regioner og lande en lang række forskellige erfaringer med tiltag og kampagner for at påvirke befolkningens adfærd. Det er derfor helt oplagt at undersøge data nærmere efter forskelle og ligheder, der kan gøre os klogere på succeser og udfordringer for folkesundheden i Norden. Det giver det nye værktøj netop mulighed for.

„Undersøgelsen viser eksempelvis, at nordmændene i gennemsnit er mere stillesiddende end finnerne. Men hvad kan forklare den forskel? Har man i Finland oplyst bedre om vigtigheden af fysisk aktivitet end i Norge, eller er der andre faktorer, der kan forklare forskellen?“ spørger Sisse Fagt, der mener at, undersøgelsen kan hjælpe forskere og beslutningstagere med at stille de gode spørgsmål, der kan bidrage til en mere effektiv indsats for sundere kost- og motionsvaner for borgere i Norden.

Sisse Fagt håber derfor, at der vil blive arbejdet videre med nogle af alle de spørgsmål, som kortlægningerne af de nordiske befolkningers kost- og motionsvaner rejser. 
„Vi ved, at hvis man ikke tidligt har lært sig gode madvaner, såsom at spise frugt og grøntsager, så er man mere udsat for at blive overvægtig eller komme til at lide af en livsstilssygdom senere i livet". Agneta Hörnell 


\section{Bedre skolemadsordninger kan forbedre børns sundhed og læring}

\section{Hovedpointer:}

- $\quad$ Den bekymrende vækst i livsstilssygdomme hos stadig yngre børn kan bremses med sundere kostvaner. Eksperter ser derfor skolemadsordninger som et oplagt indsatsområde, der ikke bare kan forbedre børns sundhed, men også deres indlæringsevne.

- Et nyt projekt undersøger, hvilken effekt skolemad har for sundhed og læring, og giver praktiske anbefalinger til, hvordan skolemadsordninger organiseres bedst.

- Projektet råder bod på den hidtidige mangel på viden om, hvordan børnene oplever skolemaden og spisesituationen.

Man ved nemlig, at hvis et barn spiser med børn, der spiser sundere end det selv, påvirkes det til også at spise sundere selv.
I Norge diskuteres det i øjeblikket, om der bør indføres skolemad til alle skolebørn. Fortalerne peger på erfaringerne fra Finland og Sverige, der længe har haft en skattefinansieret ordning. Kritikerne peger derimod på, at nordmændene ligesom danskerne har tradition for at lade forældrene løse opgaven og selv bestemme indholdet af madpakken. Island har valgt en mellemløsning, hvor forældrene betaler en andel af udgifterne til børnenes måltid.

Et afgørende spørgsmål i diskussionen er de mulige effekter af skolemad til alle. Eksperterne er enige om, at et sundt måltid giver børnene bedre muligheder for at lære. Fortalere for skolemadsordninger mener derfor, at skolemadsordninger nedbryder de sociale skel mellem de børn, der får en sund og nærende madpakke med, og de børn, hvis forældre ikke evner at sørge for det. Omvendt mener modstanderne, at det er forældrenes ansvar og beslutning, hvad børnene skal have med i madpakken.
Interessen for skolemad er også

motiveret af et ønske om at forebygge voksende fremtidige sundhedsudgifter. Fremskrivninger peger på, at en stigning i antallet af overvægtige og tilfælde af livsstilssygdomme vil få sundhedsudgifterne til at stige i de nordiske lande. Derudover peger forskning på, at sunde madvaner tidligt $\mathrm{i}$ livet har stor effekt. „Vi ved, at hvis man ikke tidligt har lært sig gode madvaner, såsom at spise frugt og grøntsager, så er man mere udsat for at blive overvægtig eller komme til at lide af en livsstilssygdom senere i livet“, siger professor i ernæringsvidenskab Agneta Hörnell.

\section{Effekt på sundhed og læring undersøges}

Agneta Hörnell står i spidsen for projektet ProMeal, der undersøger skolemadens betydning for sundhed og læring. „Det er vigtigt for Norden, at børnene har de bedste forudsætninger for at lære. Derfor bruger vi mange penge på skolemad, men vi kan ikke rigtig sige, om det har en reel effekt på sundheden og læringen“, siger hun.

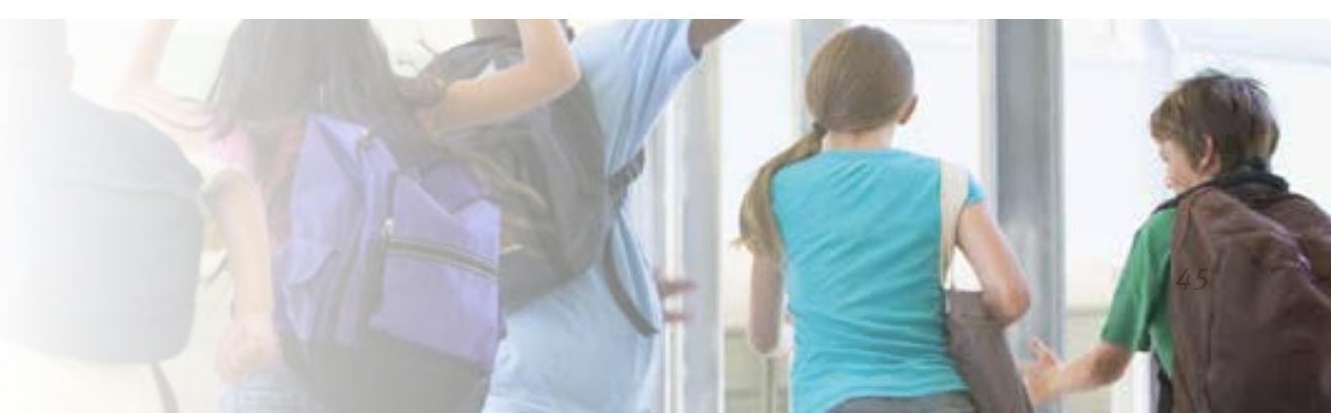




\section{PROJEKT}

\section{ProMeal: muligheder for at fremme sundhed og læring med skolemad i Norden}

\section{Formål:}

At undersøge effekten af sund skolemad på læring og sundhed og udarbejde anbefalinger til , hvilke skolemadsordninger der giver den største effekt

\section{Ansvarlig organisation:}

Umeå universitet, Umeå, Sverige

\section{Projektleder:}

Agneta Hörnell, professor i ernæringsvidenskab
Projektet, som er tildelt midler efter et udbud administreret af NordForsk, er igangsat, efter at en kortlægning af eksisterende viden viste, at der på netop dette afgørende punkt manglede viden. Denne kortlægning blev gennemført for Nordisk Ministerråd af SINTEF, en uafhængig norsk forskningskoncern.

Flere eksperter mener, at effekten er afgørende for såvel sundhed som indlæringsevne. Päivi Palojoki, der er en del af projektets referencegruppe, er professor ved læreruddannelsen på University of Helsinki, og han tøver ikke med at lave sammenkoblingen. „Den velorganiserede skolemadsordning er en del af fundamentet for Finlands flotte resultater i PISA-undersøgelserne“, siger han og fortsætter: „Skolemaden er enormt vigtig, for sultne elever har ikke energi til at lære“.

\section{Praktiske anbefalinger}

For at komme nærmere et svar prøver Agneta Hörnell og hendes kolleger at finde ud af, hvilke former for skolemad der giver en positiv effekt. „Vi håber at komme frem til ting, som kan omsættes til praktiske løsninger. Derfor følger et advisory board projektet, så de kan hjælpe os med at gøre den indsamlede viden brugbar ved hjælp af praktiske anvisninger og anbefalinger“, fortæller Agneta Hörnell.

Projektet vil undersøge erfaringer med skolemad i Sverige, Norge, Finland og Island og inkludere forskere og eksperter fra alle fire lande. Ideen er, at de forskellige landes projektgrupper har ansvaret for enkelte dele af det overordnede projekt, men alle elementer af undersøgelsen udføres i alle landene. Ambitionen er, at projektet ikke bare indsamler erfaringerne fra de fire lande, men også vil bidrage til at skabe et stærkt forskningsnetværk på området.

Professor i ernæringsvidenskab på Island Universitet, Ingibjörg Gunnarsdóttir, repræsenterer Island i ProMeal-projektet. Hun understreger, at der er behov for mere viden på området. „Projektet er meget vigtigt, for selvom vi har en idé om, at skolemaden er betydningsfuld, så har vi ikke forskningsmæssigt belæg for, hvilken type af skolemad, der har en positiv effekt", siger hun. Agneta Hörnell supplerer: „Der er kun få internationale studier, der er relevante for Norden, for meget forskning handler eksempelvis om fattige om- 


\section{Bedre skolemadsordninger kan forbedre børns sundhed og læring}

råder i USA eller om udskiftningen af fastfood med sundere alternativer på engelske skoler. Det er tvivlsomt, om disse studier er relevante i en nordisk sammenhæng“.

Børnenes perspektiv er afgørende Hörnell og Gunnarsdóttir peger samstemmigt på, at vi særligt ved alt for lidt om, hvordan børnene oplever måltidet. Ingibjörg Gunnarsdóttir understreger, at det er vigtigt at inkludere børnenes perspektiv, hvis skolemaden for alvor skal gøre en forskel for alle børn. „Vi ved faktisk ikke, hvad børnene kan lide“, som hun siger.

Agneta Hörnell er enig og har derfor inkluderet observation af skolebørn i projektet. „Der mangler systematiseret viden om, hvordan børnene oplever skolemaden. Der skal jo serveres noget mad, som børnene vil spise, for ellers hjælper det ikke noget. Derfor har vi tænkt os at benytte metoder såsom observationer, interviews, samt at børnene selv skriver, hvad de tænker om skolemad“, siger Agneta Hörnell, inden hun fortsætter: „Man ved, at spisemiljøet spiller en meget stor rolle for, hvad børn synes om måltidet. Vi har også en formodning om, at nogle ordninger gør det stressende at spise skolemad. Det kan både være, fordi børnene skal spise i et meget stort og støjende lokale, eller fordi de måske ved, at de kan løbe ud og lege, så snart de har spist færdigt“.

Projektets analyser skal resultere i praktiske anvisninger til, hvordan den sociale situation kan bruges proaktivt til at gøre den sunde mad til en normal kost. „Vi ved eksempelvis, at hvis et barn spiser med børn, der spiser sundere end det selv, påvirkes det til at spise sundere selv. Man kan sige det sådan, at spiser kammeraterne sundt, så spiser man selv sundere“, siger Agneta Hörnell.

Arbejdet er i fuld gang, og den første dataindsamling sker i løbet af i år. Senere skal de foreløbige konklusio- ner og erfaringer diskuteres på en fællesnordisk konference, sådan at konklusionerne og anbefalingerne når en bredere målgruppe.

\section{Ingibjörg Gunnarsdóttir har som} ekspert i ernæring mest beskæftiget sig med konsekvenserne for sundhed og glæder sig nu til også at undersøge skolemadens effekt på børns indlæringsevne. „I dag ved vi meget mere om sundhedseffekterne af nærende kost, end vi gjorde for 20 år siden, men vi ved stadig for lidt om konsekvenserne for børns læring og mentale udvikling“, siger hun.

Hun mener, at projektets vigtighed netop skyldes denne kobling mellem sundheds- og indlæringseffekter. „Vi har brug for mere viden om, hvordan sammenhængen er mellem, hvordan børn spiser, og hvordan de opfører sig og lærer“, siger hun.

\section{„Vi ved eksempelvis, at hvis et barn spiser med børn, der spiser sundere end det selv, påvirkes det til at spise sundere selv. Man kan sige det sådan, at spiser kamme- raterne sundt, så spiser man selv sundere“. Agneta Hörnell}

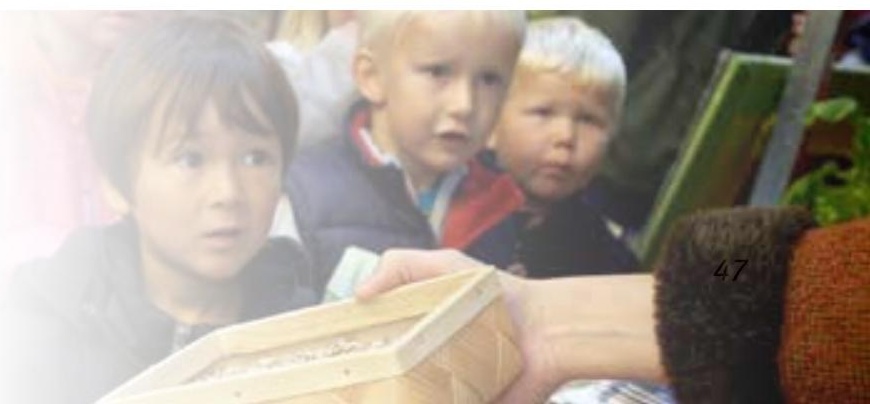


„Offentlige udbud er stadig et felt under udvikling, og der er en voksende interesse $i$ alle de nordiske lande. Ved at samle kræfterne kan vi gøre Norden til en frontløber for innovative udbud i sundhedssektoren“, Arvid Løken 


\section{Nordiske regioner samarbejder om mere innovation i sundhedssektoren}

\section{Hovedpointer}

- Udgifterne til sundhedssektorerne i Norden er i hastig vækst. I Finland er den årlige vækst i sundhedsudgifterne på 4,6 pct. Og i Danmark er der sket en samlet stigning på 39 pct. siden år 2000.

- Det hastigt voksende udgiftspres kræver generelt innovation i sundhedssektoren og specifikt i indkøbs- og udbudsprocesserne. Behovet forstærkes af, at kultur og incitamentsstrukturer i dag skaber en tendens til at købe gårsdagens teknologi.

- Innovative udbud kan være vejen frem. De giver virksomheder mulighed for at innovere processer og arbejdsgange som en integreret del af et udbud.
Sundhedssektoren udgør en væsentlig del af de offentlige udgifter i de nordiske lande. Og udgifterne vokser hvert år. Se tabel 1. I Danmark er udgifterne til sundhedsvæsenet steget med hele 39 pct. fra 2000 til 2011. Det svarer til 27 milliarder DKK. Et stigende antal tilfælde af livsstilssygdomme er bare en af årsagerne til, at udgifterne forventes at stige i de kommende år. Der er derfor et stort behov for både bedre og billigere løsninger.

\section{Bjørn Grønli er head of innovation} for Helse Sør- Øst, en af Norges fire sundhedsregioner. Han har stået $\mathrm{i}$ spidsen for et projekt, der undersøger mulighederne for at skabe mere innovation og bedre løsninger ved at inddrage flere aktører i nye samarbejds- og partnerskabsformer. Og særligt et område er ifølge Bjørn Grønli lovende.

„Det blev hurtigt klart for os, at offentlige indkøb er et centralt område, og at det offentlige kan bruge sin indkøbsmagt til at styrke fornyelse og modernisering af sundhedssektoren“, fortæller han.

\section{Køber gårsdagens teknologi}

Bjørn Grønli efterlyser langsigtede udbudsprocesser, der bygger på en tættere dialog med leverandørerne. „I sundhedssektoren har vi haft en tendens til at købe gårsdagens teknologi, som vi kender godt", siger han. Typisk bruger sygehusene udbud til at finde den billigste pris på den løsning, de allerede bruger. Hvis sygehusene skal købe fremtidsorienterede løsninger, kræver det ifølge Grønli udbud, som er åbne for nytænkning.

„Den teknologiske udvikling i sundhedssektoren går så hurtigt, at det er nødvendigt at have en mere åben dialog med leverandørindustrien“, siger han. Derfor mener han, at det store forbedringspotentiale netop findes $i$ et bedre samarbejde mellem private virksomheder og det offentlige. 


\section{PROJEKT}

Nordiske regioner samarbejder om mere innovation i sundhedssektoren

\section{PROJEKT}

\section{Innovation og entreprenørskab i sundhedssektoren}

\section{Formål:}

At afdække barrierer og potentialer for et bedre offentlig-privat innovationssamarbejde i de nordiske sundhedssektorer

\section{Ansvarlig organisation:}

„Task force for innovation og entreprenørskab i sundhedssektoren“, bestående af repræsentanter fra nordiske styrelser, ministerier og regioner

\section{Projektleder:}

Bjørn Grønli, head of innovation, Helse Sør-Øst, Norge

\section{Elektroniske tavler giver mere tid med patienterne}

Et eksempel på et sådant samarbejde er det udviklingsarbejde, som den norske virksomhed Imatis har haft med Region Sjælland i Danmark. Virksomheden havde en idé til, hvordan elektroniske whiteboards kunne erstatte gammeldags tavler på skadestuer. Sammen med forskere fra Roskilde Universitet har de derfor udviklet en ny løsning, som nu er implementeret på hospitalerne i Region Sjælland. Denne proces hjalp virksomheden til at videreudvikle tavlerne til sygehusenes behov.

„Tavlerne har udviklet sig ret meget undervejs. Vi har indbygget en fleksibilitet, som tillader læger og sygeplejersker at tilpasse tavlerne til deres respektive arbejdsprocesser", fortæller Morten Andresen, som er stifter og vicedirektør for Imatis. „Ved at observere arbejdsprocesser og brugen af tavlerne gik det op for os, at tavlerne ikke bare er et teknologisk, men også et meget stærkt organisatorisk værktøj“, siger han. Samarbejdet gav altså virksomheden en bedre forståelse af, hvad deres eget produkt kan bruges til.

Region Sjælland har som kunde også haft stor gavn af samarbejdet. Tavlerne har sikret en smartere deling af informationer mellem skadestuen og resten af hospitalet og har dermed effektiviseret det ambulante tilbud. Opgørelser viser, at en sygeplejerske på skadestuen i Holbæk i løbet af en arbejdsdag i gennemsnit kan bruge 44 minutter mere sammen med patienterne. Det svarer til, at den gennemsnitlige tid med patienterne er steget med hele 65 pct. Se tabel.

Produktet er da også ved at blive en regulær eksportsucces. Imatis har allerede indgået kontrakter med sygehuse i både Canada og New Zealand. Bjørn Grønli er meget opmærksom

\footnotetext{
„Globaliseringsinitiativet har jo netop vist, at der er en idé $\mathrm{i}$ at samarbejde, og det er det, vi bygger videre på i Holdbar Nordisk Velfærd“. Siv Merethe Lien
} 


\section{Nordiske regioner samarbejder om mere innovation i sundhedssektoren}

Sundhedsudgifterne stiger

\begin{tabular}{l|c|c} 
& $1990-2000$ & $2000-2008$ \\
\hline Finland & 1,0 & 4,6 \\
\hline Danmark & 2,1 & 3,7 \\
\hline Sverige & 1,6 & 3,6 \\
\hline Norge & 4,1 & 1,7 \\
\hline EU-15 & 3,6 & 4,0 \\
\hline OECD & 3,8 & 4,2 \\
\hline
\end{tabular}

Tabel 1:

Gennemsnitlig årlig vækst i sundhedsudgifter pr. indbygger, 1990-2000 og 2000-2008, pct. per år

Kilde: OECD Health Database, 2010

Intelligente tavler sikrer mere tid med patienterne

\begin{tabular}{l|c|c}
$\begin{array}{l}\text { Sygeplejerskes tidsforbrug før og efter } \\
\text { implementeringen af de elektroniske } \\
\text { whiteboards }\end{array}$ & Før & Efter \\
\hline Med patient, pct. & 17 & 28 \\
\hline I reception, pct. & 55 & 44 \\
\hline Anden aktivitet, pct. & 27 & 28
\end{tabular}

Tabel 2:

Kilde: professor Morten Hertzum, RUC, november 2011 på eksportpotentialet og understreger perspektiverne i at udvikle nye løsninger i et nordisk samarbejde. „Sygehuse har en grundstruktur, som er ret ens over hele verden. At finde en løsning, som fungerer i flere nordiske lande, giver derfor rigtig gode muligheder for at eksportere løsningen videre ud i verden“, siger han.

\section{Barrierer for verdensklasse}

Morten Andresen har selv erfaring fra olieindustrien og ser et lignende potentiale i sundhedssektoren. „Vi har i Norge gennem tæt samarbejde mellem køber og leverandør opbygget en førende leverandørindustri til olieindustrien. Norden har potentiale til at gøre det samme for velfærds- og sundhedsleverandører, og det er et meget stort marked“, siger Andresen.

Der er dog en række barrierer for, at potentialet kan indfries, såsom problematiske incitamentsstrukturer, risiko-avers adfærd hos nøgleaktører samt tegn på en grundlæggende mangel på dialog og tillid mellem

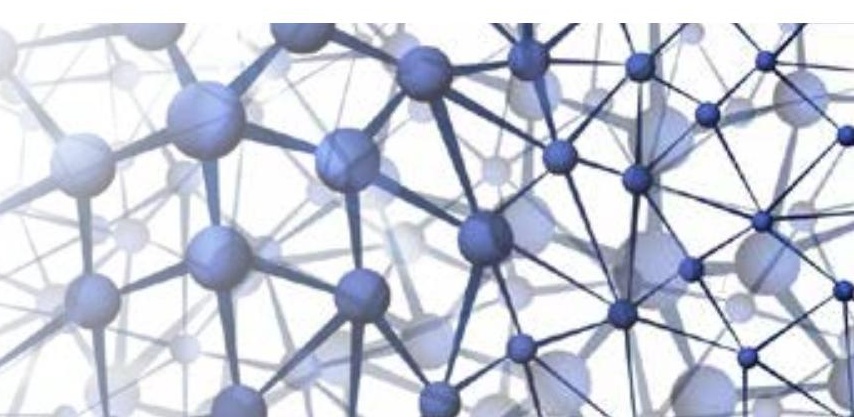


offentlige og private aktører. Som en del af Bjørn Grønlis projekt har konsulentfirmaet Damvad kortlagt disse barrierer. Se boks.

\section{Morten Andresen kan som leve-} randør godt genkende det billede: „Offentlige sygehuse opstiller ofte rigtig mange krav til deres leverandører, og det gør, at leverandørerne meget hurtigt laver løsninger, som er skræddersyet det enkelte sygehus. Dermed bliver løsningerne hverken skalerbare eller fleksible. Det gør, at hverken sygehusene eller leverandørerne opnår stordriftsfordele, og det forhøjer risikoen for, at sygehusene køber en løsning, der ikke kan videreudvikles i takt med den teknologiske udvikling“.

Direktøren ser et særligt potentiale i at udvikle løsninger, der kan skaleres og tilpasses til flere områder. „Før leverede man typisk statiske produkter, som ofte var en fiks og færdig løsning til den enkelte situation“, fortæller han. I stedet ser han et potentiale $i$ fleksible løsninger, som kan videreudvikles i samarbejde med brugere og andre kunder.

Andresen er dog også hurtig til at advare mod at gå for langt. „Der er altid en balance i dialogen med en kunde, for man skal passe på, at man ikke bliver til en slags hofleverandør med skræddersyede løsninger, som kun virker til en enkelt kunde“, forklarer han. For at sikre skalerbarhed og fleksibilitet anbefaler han derfor, at virksomheder forsøger at samarbejde med flere forskellige kunder samtidig.

\section{Innovative udbud}

Bjørn Grønli har et godt øje til de såkaldte ,innovative udbud“. Her er ideen, at eksempelvis en sundhedsregion laver et udbud, der efterspørger en løsning på et problem i stedet for efterspørge et specifikt produkt.

Det giver mulighed for at samarbejde med potentielle leverandører om at udvikle nye og anderledes løsninger,

\section{Barrierer for innovative udbud $i$ sundhedssektoren}

- Komplicerede juridiske regler for udbud

- Manglende dialog mellem parterne i udbudsprocessen

- $\quad$ Pressede budgetter begrænser muligheden for at prøve nyt

- Incitamentsstrukturer fremmer ikke innovation

- Manglende innovationskompetencer i sundhedssektoren

- En risiko-avers kultur dominerer sundhedssektoren

Kilde: TemaNord 2011:567

der kan løse problemet bedre og billigere.

Morten Andresen håber som leverandør på en øget brug af denne udbudsform: „I dag er det svært at gentænke arbejdsgangene i det offentlige. I stedet ser man typisk på, hvad man 


\section{Nordiske regioner samarbejder om mere innovation i sundhedssektoren}

\section{Barrierer for innovative udbud i sundhedssektoren}

- Komplicerede juridiske regler for udbud

- Manglende dialog mellem parterne i udbudsprocessen

- $\quad$ Pressede budgetter begrænser muligheden for at prøve nyt

- Incitamentsstrukturer fremmer ikke innovation

- Manglende innovationskompetencer i sundhedssektoren

- En risiko-avers kultur dominerer sundhedssektoren

Kilde: TemaNord 2011:567

\section{Deltagere i Nordic Public-Private Innovation Net}

- $\quad$ Region Syddanmark, Danmark (projektleder)

- Welfare Tech, Danmark

- $\quad$ Region Sjælland, Danmark

- Hospital District of Helsinki and Uusimaa (HUS), Finland

- HYKSin Ltd, Finland

- Oslo Medtech, Norge

- Helse Sør-Øst RHF, Norge

- Næringslivets Hovedorganisasjon, Norge

- Värmlands län, Sverige

- $\quad$ Region Skåne, Sverige har i dag, og videreudvikler så på det“. I Imatis er de derfor glade for Bjørn Grønlis arbejde.

„Projektet har sat potentialet og barriererne på dagsordenen. Vi oplever, at der er usikkerhed omkring procedurer og muligheder, og derfor er det så vigtigt, at projektet har skabt et stærkt netværk til udveksling af erfaringer", siger Morten Andresen med henvisning til, at arbejdet fortsætter i et formaliseret netværk af sundhedsregioner i Norden.

Netværket skal fremme innovative udbud i Norden, og Bjørn Grønli har store forventninger: „Det er første gang, jeg ser, at de større sundhedsregioner indgår i et større og formaliseret samarbejde, hvor man systematisk vil lære af hinanden. Det er i sig selv et meget vigtigt resultat“.

I netværket mødes store sundhedsaktører fra hele Norden for at dele erfaringer med at inddrage innovative udbud i sundhedssektoren.

Se boks.

Netværket skal også bidrage til udviklingen af fællesnordiske udbudsstandarder, sådan at virksomheder lettere kan byde ind på opgaver på tværs af landegrænserne. Netværket er et af seks såkaldte „fyrtårnsprojekter“, som tilsammen udgør Nordisk Innovations nye projekt „Innovation in the Health Sector through Public Procurement and Regulation“, der udføres fra 2011 til 2015.

Arvid Løken, seniorrådgiver i Nordic Innovation, er koordinator for projektet. Han er begejstret for udsigterne: „Offentlige udbud er stadig et felt under udvikling, og der er en voksende interesse i alle de nordiske lande. Ved at samle kræfterne kan vi gøre Norden til en frontløber for innovative udbud i sundhedssektoren“, siger han. 
„Grundtanken i det nye initiativ er, at de nordiske lande gennem samarbejde om velfærdsmodellen kan opnå en højere kvalitet, end landene kan hver især. Derfor er initiativet fokuseret på at fremme læring imellem landene“.

Siv Merethe Lien 


\section{Det nordiske samarbejde sætter fokus på holdbar nordisk velfærd}

\section{Hovedpointer}

- Globaliseringsinitiativet for sundhed og velfærd har bidraget med vigtig ny viden og en helt ny måde at arbejde på i det nordiske samarbejde.

- Trods gode erfaringer med det nordiske samarbejde mener den nytiltrådte generalsekretær fortsat, at potentialet er meget større. Samtidig er de nordiske lande, og midlerne i det nordiske samarbejde, små, og der er behov for at skabe øget effekt for de begrænsede midler.

- Derfor skal Nordisk Ministerråds nye program, kaldet Holdbar Nordisk Velfærd, også bygge videre på erfaringerne med globaliseringsinitiativet. Grundtanken er at udvikle innovative løsninger til fornyelse af de nordiske velfærdssamfund til glæde for Nordens 25 millioner borgere.
Nordisk Ministerråds globaliseringsinitiativ for sundhed og velfærd har skabt vigtig ny viden om centrale velfærdsudfordringer, men også peget på mulige løsninger på disse udfordringer. Således har projekterne bidraget til en betydelig udvikling $i$ det nordiske samarbejde. Samtidig har initiativet styrket det tværsektorielle samarbejde, også internt i den nordiske organisation, og ændret den måde, Nordisk Ministerråd som organisation arbejder på.

De syv projekter har styrket bestræbelserne for at få et velfungerende arbejdsmarked ved at give de nordiske lande nødvendig ny viden om arbejdsinkludering af udsatte grupper og om arbejdsforhold for østeuropæiske gæstearbejdere. Projekterne har produceret en række anbefalinger til bedre rammevilkår, der bygger på erfaringerne fra de virksomheder, som skaber fremtidens jobs.

Der er udviklet workshops og et monitoreringsværktøj, som kan fremme folkesundheden blandt de yngste nordiske borgere, og snart er ny viden og nye anbefalinger om skolemadsordninger til rådighed for nordiske beslutningstagere i regeringerne, kommunerne og skolerne. Og sidst, men ikke mindst, er en række af Nordens vigtigste sundhedsaktører knyttet sammen i et formaliseret netværk, hvor de sammen kan udvikle bedre metoder til sundhedsinnovation i de nordiske sundhedsvæsener.

Med resultater som disse i ryggen er det kun naturligt, at Nordisk Ministerråds fremadrettede arbejde også vil tage udgangspunkt i grundprincippet om, at de nordiske lande gennem samarbejde og erfaringsudveksling står langt bedre rustet til at håndtere store, globale udfordringer, end de ville gøre hver for sig. Med det nye program Holdbar Nordisk Velfærd, der står foran sin officielle lancering, fortsætter Nordisk Ministerråd det stærke fokus på samarbejdsprojekter, der adresserer de globale udfordringer for den nordiske model.

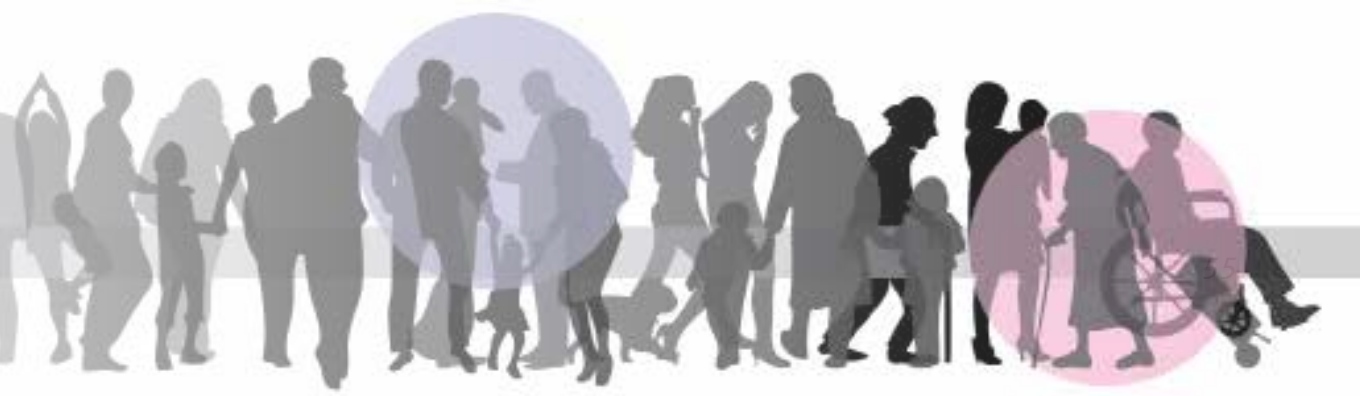




\section{Det nordiske samarbejde sætter fokus på holdbar nordisk velfærd}

Den svenske regering har gjort ungdomsarbejdsløshed til et af fokusområderne for formandskabet for Nordisk Ministerråd i 2013. Det ligger i direkte forlængelse af globaliseringsinitiativets fokus på inklusion af udsatte grupper på arbejdsmarkedet. Finansdepartementet har da også inviteret projektleder Bjørn Halvorsen med i det nedsatte advisory board for det topmøde, som formandskabet er vært for $\mathrm{i}$ maj 2013. Det sikrer, at den nye viden og de samlede erfaringer fra projektet under globaliseringsinitiativet bringes videre i diskussionen af nye og bedre nordiske tiltag for at adressere dette grundlæggende problem.

Emelie Barbou des Places er meget opmærksom på denne sideeffekt af projekterne. „Man skal ikke undervurdere nytten af at samle folk, der arbejder med et særligt tema“, siger hun og fortæller, at Nordisk Ministerråd på baggrund af de gode erfaringer fra globaliseringsinitiativet vil arbejde målrettet med at styrke dette netværksaspekt af projekterne.

\section{Holdbar Nordisk Velfærd}

„Der er ikke tale om en direkte fortsættelse af Globaliseringsinitiativet for sundhed og velfærd“, påpeger Emelie Barbou des Places. „Vi har udvalgt nogle af de faktorer, som kan gøre det lettere for Norden at håndtere globaliseringens udfordringer og derigennem sikre en fremtidssikret velfærdsmodel“, supplerer Siv Merethe Lien og påpeger, at der alligevel er en klar kontinuitet i fokus.

Holdbar Nordisk Velfærd er ligesom globaliseringsinitiativet et treårigt program, der løber fra 2013 til 2015. Det finansieres af Nordisk Ministerråds samlede prioriteringsbudget, men det fælles ansvar ligger hos Ministerrådet for Social- og Helsepolitik og Ministerrådet for uddannelses- og forskningspolitik.

Allerede på nuværende tidspunkt er det besluttet at igangsætte en række aktiviteter. Ud over de allerede nævnte igangsættes et forskningsprojekt om sociale uligheder i sundhed og velfærd og et arbejde for at øge kvaliteten, relevansen og mobiliteten i sundheds- og velfærdsuddannelserne i Norden. Derudover vil initiativet indeholde en indsats for at fremme entreprenørskab i de nordiske uddannelser, ligesom ledende nordiske økonomer skal gennemføre en grundig økonomisk analyse af den nordiske models styrker og svagheder.

Siv Merethe Lien opsummerer, at der i øjeblikket er udvalgt mere end ti projekter, og at der i løbet af den næste tid vil blive igangsat flere. Desuden vil hun og resten af initiativets ledelse opmærksomt gennemgå globaliseringsinitiativets erfaringer, sådan at også Holdbar Nordisk Velfærd bliver en succes. „Globaliseringsinitiativet har jo netop vist, at der er en idé i at samarbejde, og det er det, vi bygger videre på i Holdbar Nordisk Velfærd“, fortæller hun.

\section{„Vi har gode erfaringer med samarbejde, men potentialet er meget større. I kraft af det, vi har til fælles, kan vi opnå meget mere for både borgere og virksomheder“. Dagfinn Høybråten}





\section{nordan}

\section{Nordisk Ministerråd}

Ved Stranden 18

DK-1061 København

www.norden.org

\section{7 veje mod fremtidens nordiske velfærd}

Globaliseringsinitiativet for sundhed og velfærd er et sammenhængende program, der gennem en treårig periode fra 2010 til 2012 har været en vigtig driver i det nordiske samarbejde. Programmet fokuserer på den nordiske velfærdsmodels bæredygtighed og konkurrencekraft med udgangspunkt i centrale velfærdsudfordringer.

Konkret består globaliseringsinitiativet af syv selvstændige projekter kategoriseret under de to hovedtemaer sundhed og velfærd. Projekterne har udviklet ny viden, konkrete anbefalinger og nye løsninger. Disse resultater præsenteres her i lettilgængelig form. Publikationen består af en samlende artikel, syv projektportrætter og en perspektivartikel.

Globaliseringsinitiativets løsninger og aktiviteter peger fremad for et styrket nordisk samarbejde, hvor de forskellige lande og sektorer udveksler viden og erfaringer. Dette arbejde vil Nordisk Ministerråd fokusere på i de kommende år og vil derfor trække på viden, løsninger og erfaringer fra globaliseringsinitiativets arbejde. 